\title{
Eavesdropping with a Master: Leoš Janáček and the Music of Speech [1]
}

\author{
JONATHAN G. SECORA PEARL \\ University of California, Santa Barbara
}

\begin{abstract}
The composer Leoš Janáček (1854-1928) has been noted for his interest in speech melodies. Little discussion has focused however on the field methods that he used in gathering them, nor on the products themselves. Janáček spent more than three decades, transcribing thousands of what he termed nápěvky mluvy [tunelets of speech] in standard musical notation. The record that remains of these efforts is impressive both for its volume and its quality, as well as for its potential to reveal aspects of the perceptual overlap between music and language. Heretofore his pioneering efforts in the study of speech prosody and music perception have neither been recognized nor acknowledged. The present study provides a background for and an overview of the transcriptions, along with comparative musicological and linguistic analyses of the materials presented. With this analysis as a starting point, I indicate promising avenues for further collaborations between linguists and musicologists, seeking an integrated theory of music and language cognition.
\end{abstract}

Submitted 2006 February 26; accepted 2006 April 17.

KEYWORDS: Leoš Janáček, cognition, speech prosody, Czech language, transcription

\section{PRELIMINARIES}

THE composer Leoš Janáček had a special relationship with the melodies and rhythms of speech. Numerous attempts have sought to sustain or refute the use of speech melodies in his musical output. [2] Yet, the most tangible evidence of this relationship, the thousands of notated examples of often clandestinely overheard language, captured and preserved in his notebooks, have largely been neglected. Little presentation and discussion of these transcriptions have been made in the literature on Janáček. In the midst of current preparations in the Czech Republic to publish a complete edition of his speech melodies, and a concurrent project to digitize them, this article seeks to set a stage for their long-awaited coming out. The number of examples presented here amount to less than one percent of his output. The great majority of his notations deal with Czech prosody but also include Russian, Slovak, Croatian, English, Italian, and other languages. The group under consideration here, although limited to the various dialects of Czech, were selected to represent a broad cross-section of the materials he dealt with.

Janáček wrote mystically of the individualist force of speech melodies, their uniqueness as the public voice of a single soul, but also how that voice was irretrievably entwined with its context, an aspect which he acknowledged was somewhat lost in transcription. In one of his earliest articles regarding speech, Melodies of Children's Speech [Nápěvky dětské mluvy] (Janáček, 1904), he described his observations of a neighbor's child, whom he had known virtually from birth:

Lidka grows up with me in notes, but she also grows up in beautiful and fine surroundings. In score, no one would understand; who would not recognize that little house beneath Hukvaldy and its pleasant folks within, who would not recognize the pretty garden nearby that little house. [3]

Already here we see the roots of interpretive difficulty for future scholars, in the ambiguity of his language. What does he mean? [4] Did he actively instruct Lidka in music, as the Czech phrase vyrůstá u mne v notách implies? [5] Or did he merely observe her from a close proximity, recording in score her utterances? Did he imagine that only those who recognize the village of Hukvaldy understand these notations? Or did he intend that anyone might recognize the house and its garden, but that the musical version of young Lidka's speech was destined to remain a mystery? 
Although it is clear that his transcriptions served as mnemonics for him, recalling to his mind the experience of each recorded moment, it is hard to believe he professed that he alone could decipher the notes. If this were the case, why would he have presented them in so many articles, and most often with little in the way of explanation? [6] Such a procedure points to the likelihood that he found the transcriptions to be self-explanatory, rather than inexplicable. Whatever he thought, history instructs us that his intentions here were not entirely clear. Nor was the full course of his life yet sufficient to clarify his meaning. As late as 1928-in an interview for the journal Literární svět [Literary World] (Janáček, 1928) - Janáček complained that critics, like the outspoken Zdeněk Nejedlý, had misinterpreted his use of speech melodies.

Dr Nejedlý has reproached me for making, in effect, a musical composition out of the mass of my jottings, for putting it all together. Well, this just cannot be done. I cannot take a motive out of Mr X and put it on the back of Mr Y. For me it means something else: someone reads a Beethoven score, I read my speech motives (Zemanová, 1989, p. 122).

While his defense against the assault of Nejedlý may likely have been justified, part of the fault for the misunderstanding surely lies in his failure to articulate his ideas unambiguously. Notoriously, his articles on speech melodies were poetic, yet vague. The first of them, the Melodies of our speech outstanding for their dramatic quality [Nápěvky naší mluvy vynikající zvláštní dramatičností] (Janáček, 1903a), begins with the exhortation: "A good preparatory study for opera composers is careful eavesdropping of folk speech melodies.” (Straková \& Drlíková, 2003, p. 296) He was a refined eavesdropper himself, as he demonstrated. But we are given this mere tidbit, rather than a full-blown lesson in composing from speech melodies. The bulk of this article (and many others) is the mere record of his eavesdropping. "We will observe examples of some common speech melodies - collected on the streets of Brno," (p. 296) he wrote, and off he went, straight to the transcriptions. Accompanying his notations in this article are some spare ethnographic descriptions of the speakers and circumstances, but little else in the way of explanation. We can only assume he felt these musical vignettes provided all the context required.

In another article, My Luhačovice [Moje Luhačovice] (Janáček, 1903b), about the spa town he frequented, he wrote of speech melodies: "They are like the flowers of water lilies quivering on the quiet, happy surface of carefree life." (Straková \& Drlíková, 2003, p. 302) Indeed. A series of brief scenes follows - our dramatist setting the stage for a reenactment of this visit to Luhačovice: The coachman's call to halt his horse; the impatience of a landlord; a child's taunt; the indescribable humor of a cow's "moo" interrupting (on pitch) the bassoon line of the spa-town orchestra; an old man toting medicinal herbs. We pass through his experience, listening over his shoulder. At the end of this long day of wandering, he remarks:

You know that strange hum in a beehive, when the sun leans at first upon the highest summit of a mountain, then descends low and lower down the hillside, until it settles on the meadow below? The fundamental tone of the hum increases; thousands of bees you see, how like black dots they flit against the clear sky, then head directly toward the sun as with morning greetings (p. 304).

Janáček as our guide is charming, and clearly enamored of his own poetic vision. We notice the things he does, which may otherwise have slipped our attention. We meander through town, only at times pausing to wonder where this will all lead. When we are struck by his lack of direction, he implores us to carefully attend, as if listening will make it all clear. The transformation from observation to creation, how eavesdropping leads to composition, he leaves to our imaginations, just as it was left to his. Remember however, that when he began these writings, in 1903-six years after recording his first speech melodies [7]-he was still a little known composer, employed principally with running the Brno Organ School (later the Conservatory of Music) that he had founded two decades before. Flights of fancy at this stage in life became him. The first opera to incorporate his developing ideas on speech melodies, Její pastorkyně (also known as Jenůfa), was yet to come out, and wouldn't be premiered in Prague (bringing him recognition and acclaim) until 1916.

However, though he may have been careless in his explanations, he was not equally careless in his 
observations. Indeed he was a pioneer, in the vein of the next generation's acknowledged masters of the genre, Jean Piaget (1896-1980) and Benjamin Lee Whorf (1897-1941), who like Janáček forded new tributaries of observation. [8] There was virtually nothing written in Janáček's day regarding the melodies and rhythms of speech. Most of the linguists who would make major contributions in this regard were yet to be born. What was written often contended, without empirical evidence, that a fundamental chasm separated music from language, which Janáček clearly would have contested. Henry Sweet, whose seminal Handbook of Phonetics (Sweet, 1877) was among the first to mention the matter of pitch change in language, wrote:

Changes of tones may proceed either by leaps or glides. In singing the voice dwells without change of pitch on each note, and leaps upwards or downwards to the next note as quickly as possible, so that although there is no break, the intermediate 'glide-tone' is not noticed. In speech the voice only occasionally dwells on one note, but is constantly moving upwards or downwards from one note to the other, so that the different notes are simply points between which the voice is constantly gliding (pp. 93-94).

This assertion that music is characterized by stable pitch targets, which spoken language lacks, has been repeated numerous times (cf. van Waesberge, 1957; Pinker, 1997, in particular p. 529), but never tested in perceptual studies or documented through observational evidence.

For Janáček, clearly no such categorical distinction existed, for he found speech to contain all the musical information that he required. It is instructive to note, that Sweet provided his text with the following disclaimer:

It needs hardly be said that many of the statements in this book - whether the result of my predecessors' or my own researches - will require careful examination by others before they can be either fully received or rejected. The whole subject of intonation, especially, requires to be thoroughly investigated by a thoroughly competent observer, which I am very far from being, my natural aptitude and my training being equally defective (Sweet 1877, p. x).

Although this may principally have been the expected self-deprecating hyperbole of the late $19^{\text {th }}$ century, it warrants our attention. While Henry Sweet begged off, Leoš Janáček was an ideal candidate to be "thoroughly competent." He was a keen observer, but he didn't have the advantage afforded by a critical mass of research in the field. While some isolated texts discussing intonation appeared (in the English language) as early as the $16^{\text {th }}$ century, these were focused on the practical issue of pronunciation rather than on the broader questions of meaning and perception. [9] In any case, they would have been inaccessible to Janáček, who lacked fluency in English. [10] Consulting the mostly Slavic-source citations in a 1957 survey on the phonetics of the Slavonic Languages (Hála, 1957), the earliest reference (on Russian) appears in 1912. The earliest noted work on Czech is from 1926, two years before the composer's death.

In Janáček's own library we see a mere smattering of works addressing the matter of Czech phonetics and intonation, virtually none of them preceding his earliest efforts to collect nápěvky mluvy. Some general writings, that without doubt had bearing on Janáček's approach, did predate these: for example, František Sušil's handbook (1863) on poetic prosody, and Otakar Hostinský's (1886) work on musical declamation. However, those which specifically address Czech intonation and speech prosody appear later: Olaf Broch's (1911) Slavische Phonetik: Sammlung slavischer Lehr- und Handbücher [Slavic Phonetics: Collection of Slavic Text- and Handbooks]; Josef Chlumský's (1911) Pokus o měrení českých zvuků a slabik v řečí sovislé [An Attempt at Measuring Czech Sounds and Syllables in Continuous Speech]; Janáček's copy of František Trávníček’s (1924) volume Příspěvky k nauce o české přízvuku [Contributions Toward a Science of Czech Accentuation] includes its author's dedication to the composer; and Tucháček's (1920) article Poznámky o zjevech fonetických [Comments on Phonetic Phenomena], was also in Janáček’s library.

The titles of these last three give a good idea of the tentative state of research in Janáček's day. In each case, the timidity and hesitance of the field is evident. In addition, one of the most prominent Czech linguists from his day, František Bartoš, had recruited Janáček to assist with the recording of folk music. Their friendship and collaborations continued from their first meeting perhaps as early as 1881 until Bartoš' 
death in 1905. Bartoš was certainly privy all along the way to the composer's growing interest in and direct efforts regarding speech melody. Surely he would have been able to point his friend toward any existing theories or practice in that regard, or toward individuals active in that field of study (perhaps even František Trávníček, who wasn't born until 1888). All this is to argue that Janáček was not working from a rich foundation in Czech phonetics and intonation studies, but was himself among those founding this area of study.

For Janáček, it can be assumed that his musical transcriptions of speech were intended as accurateas-possible descriptions of his momentary perceptions. If the transcriptions have been criticized for their sometime propensity to represent speech melodies with tonal characteristics (Christiansen 2002; 2004), the evidence most needed to challenge their accuracy should come from recordings and analysis of actual speech. But we don't have an audio record of what Janáček heard. [11] We have no means of testing his acuity directly. The greater difficulty however, which must be acknowledged, is that the melodies of speech are not self-evident, objective features of the world. There is no established heuristic powerful enough to extract all and only the pitches that a hearer will perceive in any stream of speech, nor for that matter in any excerpt of performed music. The notes in both cases are theoretical, rather than absolute.

This is a fundamental dilemma for the study of perception. Human perception is an individual experience. What constitutes a note, for instance, is a subjective matter, more so in natural speech perhaps than in polished concert music. Nonetheless, even for music, where the categories of pitch have a wellestablished history, there is a range of forgivability (encompassing "expressive intonation") within which a sounded note may or may not be considered a member of a given pitch class. Most written languages lack any reference whatsoever to prosody, and those that include one, focus almost exclusively on lexical tone, rather than affective expression. The carefulness, explicitness, formality, and punctuation (Chafe, 1988) of written language are testament to this lack. We are deceived by the neatness and definiteness of written forms, whether text or score. Real experience and perceived experience are far messier than that. I believe what Janáček was heading toward in his transcriptions was an explicit articulation of his perceptions of the performed speech melodies that he heard in everyday life. If the results were stylized, seemingly more musical than speech-like, this is perhaps a simple reflection of his musical mind, fitting the fuzzy surface of spoken sound into the paradigms of his mental schemae.

Janáček was not the first nor the last to attempt a musical model for recording the prosody of speech. [12] As early as the $18^{\text {th }}$ Century, Joshua Steele had devised just such a system (Kassler, 2005). The difference however was that both earlier and later attempts have been applied almost exclusively to theatrical speech or to paradigmatic citation forms of isolated words or phrases. While a few of Janáček's transcriptions record theatrical speech or public lectures (most notably, one by Rabindranath Tagore in 1921), the overwhelming majority of them are drawn from spontaneous speech. It is this aspect of his field methods that intrigues us today, and that serves as the most promising area for further adaptation and elaboration of his work.

Every utterance of speech contains an emotional layer (affective prosody). Prosody plays a further role in distinguishing word types (lexical prosody) and in projecting aspects of the underlying grammar (propositional prosody). These are theoretical categories, each describing a different function, that remain difficult to separate acoustically, even neurologically. [13] Not enough is yet known about the cognitive processes involved in sound production, nor those leading to speech comprehension to provide a reliably objective means to distinguish them. But the prosody of speech may hold a great deal in common with the emotional and narrative aspects of music. While syntax and semantics are often the focus of linguistic research, and form the focus of musical analysis, the emotional and narrative features of both music and language present an additional and promising subject for further exploration. This area of research has yet to be fully exploited, but holds great promise for uncovering new connections between musical and linguistic understanding. Unfortunately, no thorough comparison has yet been done between the prosodic elements of different languages (synchronic variability), nor between the prosody of utterances in the same language across time (diachronic change). Even less has been done comparing such aspects of language to musical experience. [14]

The prosody of speech might be termed the musical aspects of language. But the interaction between music and speech prosody is more complicated than it might appear. For instance, one might suppose that musicians would necessarily be more adept at comprehending and manipulating these "musical" aspects of language than the average language user. But musicians don't seem to be immune to having bad accents in a second language - a good measure of prosodic ability - which one might suspect if these were ostensibly subject to the same cognitive faculty. A description of prosody as the musical aspects 
of language also creates the impression that prosody is something external to language, something ornamental, but non-essential. Such a view would fail to accommodate the reality that prosody is a universal aspect of all spoken language. It is a feature that is naturally acquired by all speakers as readily as the words and syntax of a language. Is there something in the acoustic signal that renders music distinct from language? Or is it rather an aspect of our thinking, determined by cultural and contextual expectations, that decides our judgment? In terms of the human voice, common to both singing and speaking, these distinctions become quite muddied.

\section{TRANSCRIPTIONS}

Janáček left behind a wealth of written materials, including 75 folders' worth of what are classified at the Moravian Museum Music Archives in Brno, Czech Republic as zapísniky, or notebooks. Two of the notebooks (numbered Z29 \& Z32) [15] appear to be lost, and a few of the folders contain merely random bits of paper, or pages culled from large desk calendars, scribbled with a few stray notes or markings. The bulk however are notebooks proper or pocket calendars (many designed for Czech teachers or designated as music calendars, which include dates and bits of trivia regarding music and local concerts). The calendars open with a brief initial calendar section, then follow with blank pages. In total the pages of his notebooks comprise perhaps 10,000 or more. They are mostly well-dated, beginning with the first notebook from 1879-1880 in Leipzig, Germany (where Janáček was studying for a time at the Conservatory), and continuing to the final two notebooks dated 1928, the year he died. Many of these notebooks, especially from the first two decades, contain a large section of grades registry, as Janáček was employed principally as an instructor of voice, organ, and violin. However, beginning with Z2O, dated 1897-1900, we find a notebook entirely filled with nápěvky mluvy. [16] Jottings of speech melodies continue throughout the remainder of his life, and can be found in nearly every notebook from then on. They comprise about a half of the total pages in his notebooks. In addition, his journals contain notes for lectures or articles, various mundane jottings of expenses, scheduling, descriptions of concert repertoires and performance critiques, musical sketches, as well as random musings that happened to have crossed the mind of their author, and which at times give a glimmer of his personality and interests.

As noted above, because we lack the audio for comparison, we cannot be certain of the accuracy of Janáček's manual recordings. [17] The act of transcription is one of abstracting salience and definition from a surface of sound, muddled by background noise and by fuzzy edges. In hearing these materials, we apply often unconscious expectations and biases. In reality, this is true for both linguistic and musical data. In transcribing a folk or concert performance for instance, it is necessary to decide what elements of the sound bear relevance to the act of music making. Is the sighing or coughing of an audience member or performer meaningful? Are the squeak of a bow or the sound of a finger moving along a string superfluous, or integral to the musical performance? At a more fundamental level, even the categories into which we set the raw data are predetermined by our experience and training, rather than emerging organically out of the sounds themselves. [18]

While standard western musical notation (which was the medium for Janáček's efforts) gives preference to pure pitches of the diatonic or chromatic scale and to small-integer ratios for durations, these simplifications must be drawn from a richer tapestry of possibilities. [19] For instance, meaningful glides and shifts of pitch often occur within a spoken syllable, just as infinite gradations of legato occur in musical performances. However, Janáček as a general rule transcribed one pitch per syllable. The exceptions, while telling, are somewhat rare. Clearly, therefore Janáček was focusing on other aspects of the sound, on what may be deemed more global features - the overall contour and rhythm. Perhaps he simply was unaware of minor perturbations in pitch, but more likely he considered them irrelevant or superfluous to his task, paraphenomena, rather than essential. Additionally, he may have considered notation merely a shorthand, expecting a degree of flexibility in interpreting the score. Janáček's comments indicate some appreciation for the difference between writing and sound. In an essay (Janáček, 1924), discussing the emotional power of a chord in sound and its differentiation from any mere representation of it, Janáček wrote:

Musical instruments, tuned by fourths and fifths, with their diatonic or chromatic scales, and quarter or sixth-tones, are a serious obstacle to the expressive value of a chord. And their notation, too! The chordal expression becomes stylized-and stiffened. Try to stylize, in the same way, the rounded movement of the hands, the pallor or the brightness 
of colour, the flowing movement of the eye-the attempt can only be laughable.

Against the expressive chord stands a chord acoustically calculated, smoothed out, ascetically refined, grown cold, a chord made glib through education. To choose out of these chords? If you reach for the latter, you are reaching for someone else's ready-made work. You are withdrawing from the living source of expression; you are getting nearer the graphic rather than the expressive. [20]

In defending the use of speech melodies as inspiration for his compositions, he described the practice of recreating melodies in his mind from transcriptions as being akin to reading a musical score, and thus implicitly subject to the same degree of flexible interpretation (Janáček, 1928). It is therefore natural to assume that Janáček sought a means to record these phenomena which accorded with his own interests, understanding, and biases, rather than any established norms and theoretical frameworks. [21] His notations of speech must necessarily have followed the unwritten rules of simplification that are normally applied to the notation of music, a tacit understanding that performance may veer from the absolutes of notation without being untrue to the spirit of the score. [22]

We may consider these transcriptions stage notes for the reproduction of the original events, most especially in the mind of the composer himself, but secondarily by anyone reading them in score. Such a tack is consistent with an appreciation that Janáček was selective in which elements of an event he fully notated, and which were otherwise described, paraphrased, or simply written out as text without musical notation. Assumedly, the composer resorted to the greatest degree of detail, when this detail was most relevant or unusual, and thus required fuller description. Moreover, it helps to explain why Janáček chose at times to notate what might otherwise be seen as uninteresting and trivial, such as his numerous single pitch nápěvky, or the mundane two-pitched expressions such as: prosím [excuse me] or ano [yes] that pepper his notebooks. Taken in isolation, such examples seem pointless. As part of an anecdotal recreation of a scene from life, however, they can be viewed as fuel for the dramatic furnace, which Janáček professed as one of his main motivators in this enterprise.

For both music and language the transference from sound to writing, and back from writing to performance, permits us a unique vantage for viewing the filtering process through which approximation takes place. We can thus expose the elements that are deemed (often unconsciously) by participants as most important for the behavior at hand. Much more study and analysis will need take place in this domain before meaningful patterns will emerge, and usable conclusions can be drawn. However, it is a danger to begin with a theory, to preordain the structures considered of significance, and proceed to fit the data to that model. Rather, it were better to begin with data, apply a multitude of analytical efforts to this data, and build a model on the basis of the patterns that arise from those efforts. The ethologist and primatologist Frans de Waal (2001) has made a similar argument for the behavioral sciences in general:

The urge of behavioral scientists to proceed in a straight line from theory to data, hence presenting themselves as more naive to the truth than they actually are, derives from a desire to be like physics, a science that has reached the lofty stage of armchair prediction. $\ldots$

It is unclear whether the behavioral sciences will ever reach the point when logically derived predictions drive progress. Behavior is more variable than the dance of photons, and its explanation involves multiple layers, from the physiological to the mental. We cannot afford to look through a single pair of glasses; we need lots of different glasses to see reality. Theories do assist in this effort, by guiding our attention and making large amounts of data graspable, but they also induce selective blindness ( $\mathrm{p}$. 182).

The data we begin with then are Janáček's transcriptions of speech. The analysis below is one volley in the effort to establish an integrated theory of music and speech perception. 


\section{To Loaf is a Crime: 1897, the Nápěvky Begin}

This first example (Figure 1), from the year 1897, appears at the top of the first page of notebook Z20, the first of Janáček's to contain speech melody transcriptions. [23] A teacher presents: zaháleti je hř́ch [to loaf is a crime]; the pupil repeats: zaháleti je hřich. These two utterances are notated as melody, followed by simple text (without notation): prodávati není kupovati, zaháleti jest sloveso [To sell is not to buy, to loaf is a verb], along with the remark that all of this was overheard at the Brno Teacher's Institute, $3^{\text {rd }}$ class, in the neighborhood of Žabovřesky in Brno. This is the first notated speech melody recorded by Janáček. The notebook Z20 is entirely filled with such notations, and appears out of the blue. We will never quite know what prompted him just at that moment to begin. But for the remaining 32 years of his life, he seems hardly to have stopped.

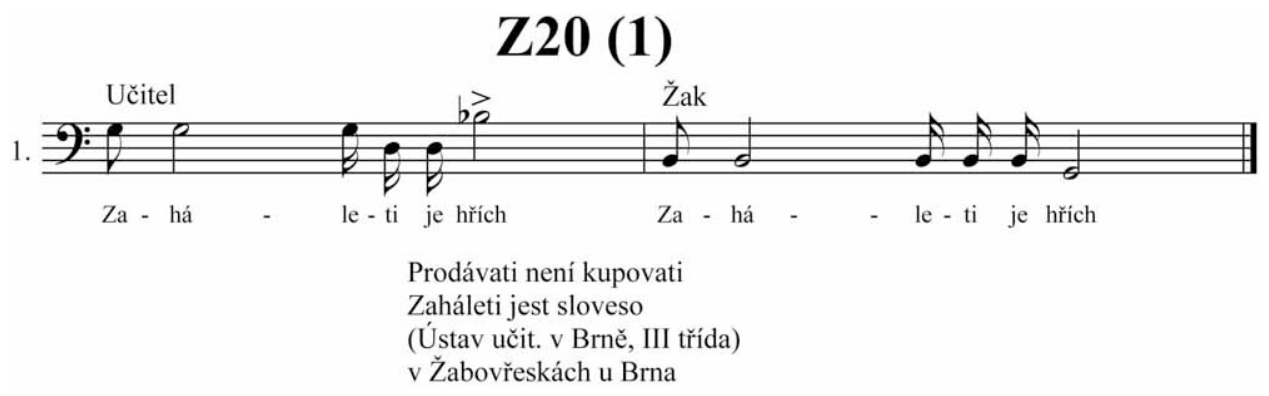

Fig. 1. To loaf is a crime. (Use the following link to download the audio file for this example: https://kb.osu.edu/dspace/bitstream/1811/24010/1/EMR000009a-Eaves01.ogg)

What is charming about this nápěvek is how Janáček has captured the mood of the moment. The melodies of both sections fit perfectly into a reasonable musical call and response pattern: the first measure providing a G-minor motive, with its response in G-major, ending on the tonic. Intonationally, the leap up from a $\mathrm{D}$ to the $\mathrm{B} b$ on the final syllable of the teacher's statement renders that syllable (in this case a singlesyllable word) the most prominent. In case the point was otherwise missed by the pitch accent alone, Janáček marked this $\mathrm{B} b$ with a musical accent mark, making his perception clear.

Assumedly, based on the text that follows the notation, this extract is from a vocabulary lesson, and the teacher continued with the remaining text, though Janáček chose not to notate their melody. In what is notated however, the teacher emphasized not the verb itself, but his description of that verb, making it clear that his lesson was intended as a statement about the matter of idleness, as much as anything else. The student's response might be described as bored. It has been observed as a common feature of spoken language that the majority of utterances rest in the lower third of a person's vocal range, and thus the majority of pitch accents will be to a higher register (Cruttenden, 1996, pp. 45, 124). The student's motive however lies at the lower end even of the singing range for a deep bass, in what for most of us would be the region of vocal fry, likely indicative of a decreased energy level. The nearly monotone utterance, with a fall at the end, stands in contrast to the teacher's model. Musically, however, we see a textbook resolution to the opening melody, landing as it does on the $\mathrm{G}$ an octave below the opening note.

We should observe that a prominence lies, in both the model and the repetition, on the second syllable of zaháleti. This prominence is created entirely by an agogic accent, as there is no pitch movement to or from this syllable, in either case. Theoretically standard Czech is characterized by fixed initial stress, meaning an accent naturally falls on the first syllable of every word. What leads to a perception of initial stress however is somewhat contentious. Vowel length, while potentially serving as a cue to stress (as in this example), is contrastive in Czech, with diacritical marks (á, ý, í, etc.) serving to denote length in writing. Thus, we have many words with a short accented initial syllable, followed by a longer ostensibly unaccented syllable (as for instance in the name Janáček).

Thus, the longer duration of the second syllable here might be attributed to vowel length, but the half-note Janáček writes is far longer in relation to the surrounding durations than vowel length alone would require. Yet all long vowels in this example are notated by half notes. Lacking a pitch movement, we can consider this agogic accent to represent what would be described linguistically as a secondary accent. If we assume Janáček's notation to accurately reflect the performance, we might consider this over- 
lengthening an aspect of the type of utterance, being more formal (in a classroom setting), and thus perhaps with exaggerated differentiation of vowel lengths. Alternately, we might argue that Janáček's transcription rather reflects his intention (instead of that of the speakers') to exaggerate these durations.

Because there are two speakers, and based on internal features of their utterances, we have what should be considered two separate nápěvky. In the linguistic literature, this sort of unit has been described under various names, with slightly different theoretical assumptions applied to each. I will describe them as intonation units, with explanation to follow. In this case, the contour as notated of the first utterance - that of the teacher-is best described simply as a rise; and the second-that of the pupil-is best described simply as a fall. This describes the pitch movement surrounding the primary accent, in both cases here the final syllable. Perhaps a more complete description of the teacher's motive would be as fall-rise, which describes the movements in toto. Although there are several approaches in practice within the field of linguistics, the general consensus appears to be that the classification of contours begins with the pitch movements that surround the primary accent, rather than encompassing all pitch movements of an utterance.

There are various approaches within the field of music theory as well, some of which concur that all pitches are not equally important for analysis. We might commonly describe a motive as rising, despite momentary dips in pitch, as long as the overall shape of the melody is perceived as rising, principally by ending higher than it began, and through recurrent stepwise or leapwise motion upward during its course. In general, the musical description would follow what could be termed the gestalt of the melody as perceived by a listener. Further, certain approaches, such as Schenkerian analysis, prescribe reductions to the data that are in effect similar to reductive procedures in linguistics. The linguistic approach, perhaps more so than the musical one, has not been guided so often by a desire to describe the overall gestalt however, as by theoretical considerations, in an attempt to capture the meaningfulness of these melodies. [24] For some, this is driven by the belief that only through abstracting salient features from the details will we be able to recognize perceptual equality and perceptual equivalence ('t Hart, Collier, \& Cohen, 1990, pp. 42-62). Only by simplifying the surface details of speech melody will we be able to notice similarities among these instances that otherwise go unnoticed.

This is akin to a common issue in the sciences of determining the level of observation. At differing levels, distinct similarities and differences become apparent. While the microscope allows comparisons of physical materials imperceptible to the naked eye, it likewise obscures many of those which would otherwise be observed (on a larger scale). The choice is motivated by the sorts of questions we wish to ask. In music-theoretical terms, resorting to pitch class set theory permits comparisons of interval content which are likely inaccessible to a listener, and in any case are removed from acoustics and auditory perception. Similarly, examination of diachronic spellings of chords permits us a glimpse into the intentions of the composer beyond that obtainable through perceptual investigations of the sounds themselves.

I would propose that the concept of prominence, and the related ones of primary and secondary accents (some linguists even speak of tertiary accents) are easily transferable to musical materials. Prominence is a commonplace within a metrical approach to music analysis. However, a strict adherence to meter is not likely to be found in expressive performances, whether of the concert variety, in folk music, or spontaneous lullabies. The approach that I advocate here is one that pays attention to actual performance, rather than relying on scores alone. Some aspects of this analysis however will remain apparent on the page, such as a pitch accent or agogic stress. Since we don't have access to the actual performances of these speech melodies, but merely the record preserved by Janáček, it is necessary to rely upon them, filtered through our own intuitions as we read them.

One problem that we run into in considering and classifying Janáček's transcriptions is the fact that for the most part he avoids notating multiple pitches for any given syllable, and mostly avoids the notation of any glides between pitches. From a linguistic standpoint, this would be rather unusual in spoken utterances, as pitch movement within a syllable, especially an accented one, is quite common. This harkens back to the comments of Henry Sweet, who sought to distinguish speech from music by the absence or presence of a perceptible glide-tone (Sweet, 1877, pp. 93-94, quoted above). As noted, there is some dispute over the veracity of Sweet's observation as a universal feature of perception, despite the fact that this sort of view has been repeated many times over the past century, as for instance, Steven Pinker's observation:

[Musical] notes are played and heard as discrete events with beginnings and ends and a target pitch or coloring. That sets music apart from most other streams of sound, which 
slide continuously up or down, such as a howling wind, an engine roar, or the intonation of speech (Pinker, 1997, p. 530).

In contrast, Alan Cruttenden has proposed that preferences for jumps or glides are actually languagespecific rather than universal characteristics of language (Cruttenden 1996, p. 46).

Further, it should be noted that Sweet's observation clearly deals with perception not acoustics or physiology, and thus is a more complicated matter than he may have believed. He seems to have been unaware of his own culturally-based perceptions that led him to certain judgments, which caused differing percepts for speaking and singing. van Waesberghe (1957) makes similarly questionable remarks regarding the differences between speaking and singing, which may reflect his own proclivities, or his assumptions about the general public, more so than they express perceptual universals:

[A] speaker will occasionally slightly vary the pitch; these nuances will at once be registered and interpreted by the hearer, even though the duration may be much shorter than is the case in music. It is curious that a person, even with a sensitive ear, will not note the ascending or descending pitch of a singing choir, yet will react faultlessly to the slowly rising or falling pitch of the voice of an orator or a reciter. In the monotone reading of a text even a layman in music will soon or after a while become conscious of the rise or fall in pitch.

Experimentally therefore we establish this contrast between speech and music: slight differences of pitch are spontaneously perceived and interpreted by the hearer, while in music they hardly impress the ear at all, or if they do, they are not appreciated as differences of pitch (p. 374).

In addition, while it might be logically assumed that a musician would be more adept at accurately perceiving pitch in speech, this notion is somewhat contentious, having been challenged by some researchers specializing in the study of perception, yet sustained by others. ' $t$ Hart, Collier, and Cohen (1990, p. 28) have observed: "We have reasons to believe that the identification of musical intervals is not relevant to the question as to how accurately pitch in speech is perceived." A recent article by Schön, Magne, and Besson (2004), however argues that extensive musical training does effect a beneficial gain in the perception of intonation in speech. But note the words of Collier (1991): "Prosodic features are probably the most evasive properties of spoken language. It is notoriously difficult to put into words one's impression...".

To return to Janacek's perceptions, as they are preserved in his transcriptions, one might surmise, in accordance with some of his own statements, that he was attuned to the melody and rhythm of speech more so than the average listener, even more so than the average musically trained one. This attention to the prosody of language, as if it were music, is reflected in his notational practice, which lends itself to certain sorts of judgments regarding pitch and rhythm: those that fit neatly into the schemae of a musician's mind. In this vein, despite the questionability of the remarks quoted above, van Waesberghe (1957) astutely observed:

The whole of the musical scale is made up of a limited series of tones of specific pitch and in listening to music the ear is so predisposed to hear one of these tones that it presumes it hears them. Perhaps the contrast between those who listen to music and those who listen to a speaker may be illustrated thus. It is the difference of attitude in the hearer that accounts for the perception or non-perception of nuances of pitch in the two cases (p. 374).

One might say, however, that this "difference of attitude" is not so much the result of the materials under observation (musical or linguistic), as van Waesberghe supposes, but rather due to the predispositions and abilities of the listener. In this way, what the general public might not be aware of, and what others might hear as pitch glides, by Janáček may have been heard as stable diatonic pitches. Unfortunately, what we have to go on is neither the recorded sounds themselves, nor any objective measure 
of the composer's perceptions, but merely the remnants of his experiences, as they were captured on paper in his notebooks. Yet, these in themselves, as we shall see, are enlightening and remarkable bits of evidence to consider.

\section{Intonation Units, Anacrusis, and Other Concepts}

Presented on page 4 of Z20 are three nápěvky apparently unrelated by content, though all uttered by the same woman, assumedly during the same period of time. She is described at the top of the page as pí. Rakosičová, klidná, s melodickou řeči [Mrs. Rakosičová, peaceful, with melodic speech]. Janáček, as was his custom, marks _ _ _ between the scores, as if to demark separation. The first (Figure 2, No. 10) presents us with a clear example of anacrusis. This is one of those few terms that is shared between musicology and linguistics. The word derives from the Greek meaning an "up-stroke" (Oxford English Dictionary, 1989, s.v. anacrusis). Musically, an anacrusis has been described as "[o]ne or more notes preceding the first metrically strong beat of a phrase; upbeat, pickup.” (Randel, 1986, s.v. Anacrusis) Linguistically, the term has similarly been used to refer to a series of unaccented syllables at the beginning of a stretch of speech, normally uttered with a quickened tempo (Chafe, 1994, p. 59; Cruttenden, 1996 , p. 21; Du Bois, Cumming, Schuetze-Coburn, \& Paolino, 1992, p. 100). [25]

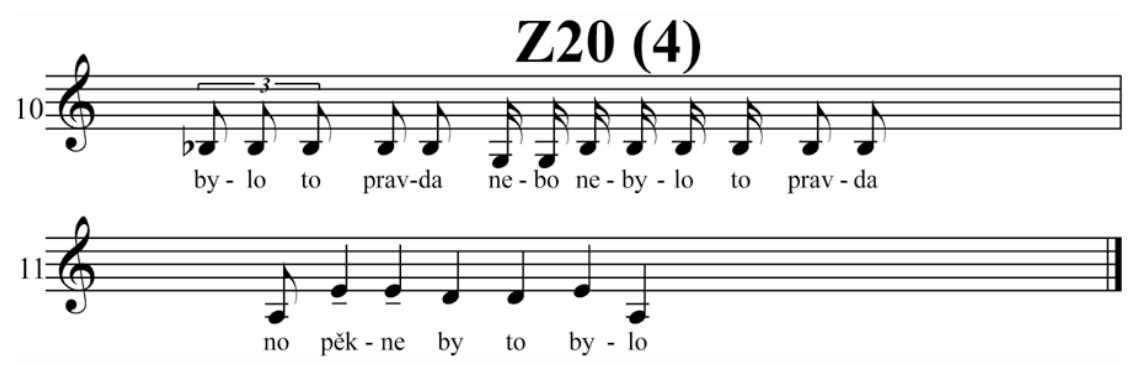

Fig. 2. The truth. (Use the following link to download the audio file for this example: https://kb.osu.edu/dspace/bitstream/1811/24010/2/EMR000009a-Eaves02.ogg)

This first can clearly be divided into two sections or intonation units. The initial section bylo to pravda [it was the truth], the second nebo nebylo to pravda [or was it not the truth]. The Czech here is ambiguous as to whether this is a statement or a question. No question mark is written, but neither is any form of punctuation. The construction in Czech would be the same in either case, though assumedly the intonation would differ, thus giving us a cue to the intention of the speaker. In this example however the intonation itself is ambiguous. Lacking the contextual information that the participants had, it is impossible to determine. Perhaps this ambiguity was the precise thing that piqued Janáček's interest, and gave him impetus to notate it.

While the length of this utterance (at 13 syllables, it is nearly the longest recorded by Janáček) is motivation enough to suspect perceptual subgroups, division into two intonation units is clearly indicated by anacrusis, and arguably by lengthening. Anacrusis is a major cue, along with what is termed pitch reset (a return to a baseline pitch level), to the beginning of an intonation unit (Ibid., p. 100). [26] Lengthening is a cue to the ending of an intonation unit, just as a ritardando (written or not) is typical of phrase endings in music. Anacrusis is indicated here by three triplet-eighths in the first case, and by six sixteenth notes in the second part. I say lengthening is arguably a factor since, in this sort of utterance, all that remain after the anacrusis are accented syllables, in both cases here on the word pravda [truth], and in both cases realized by two eighth notes.

Pitch reset is also arguable in this example, but presents an interesting problem. This utterance is entirely on the pitch $\mathrm{B} b$ below middle $\mathrm{C}$, with the exception of the two syllables of the word nebo, which lie a minor 3rd below on $\mathrm{G}$. The pitch reset then rests, not at the beginning of our hypothesized second intonation unit, but rather on the second word nebylo. Yet convention, and the concept of anacrusis, would lead us to begin the intonation unit with the sixteenth notes of nebo. This may be evidence that pitch reset in speech may on occasion, or perhaps even typically, lag behind anacrusis. With this example as a starting point, one might hypothesize that conjunctions - just as they do syntactically — serve a transitional function 
prosodically. [27] Possibly this is a language-specific characteristic. But this will only be determined by examining a variety of cross-linguistic evidence.

The concepts of intonation unit, anacrusis (especially in the linguistic sense, which seems to encompass more occasions than the strict musical usage as upbeat), pitch reset, and lengthening, all correspond in varying degrees to music as well. Lengthening is an interesting case, as it is noticeable both in score and in performance. While many composers have chosen to notate a ritard at the end of sections (this is particularly common in Baroque chorales), it is also a known feature of most performances of Western common practice music that tempos slow to a final cadence. Whether this feature will prove universal, across musical cultures, is not yet known. The use of fast, unaccented notes at the beginning of musical phrases is certainly a testable hypothesis, and warrants the effort of analysis across a broad range of musical materials. Pitch reset is without a doubt akin to the concept of tonality (and as already mentioned the use of recitation tones in many forms of chant). One obvious difference of course is the greater flexibility allowed in speech. However, a fairer comparison might not be to instrumental scores, but rather to singing practice, especially unaccompanied. In this context, I suspect that much greater flexibility (or instability) of pitch will be in evidence. [28]

Finally, the idea of an intonation unit as the basic unit of speech utterances can be examined for its relationship to musical phrases. [29] One aspect of this is the contention that intonation units comprise a coherent or unified intonational contour. The question of coherence in this sense permits us to examine what elements are necessary and sufficient to provide such containment, and how this correlates both to the perception and cognition of listeners, performers, and composers. A thoroughgoing examination of the relationship of these ideas in music and in language will surely reveal difference, but just as certainly will uncover many unexpected similarities. For one example, musical phrases often overlap, with one chord or note serving both as resolution in one phrase and the initiation of a new one. While speech does not contain an equivalent to harmony, there definitely is overlap, with one speaker beginning while another is still engaged. Unusual events sometimes occur, where an intonation unit is interrupted, and later continues, whether by parenthetical comments, or by another speaker or sound event in the environment. Correlates between music and language of these kinds can be found and further examined.

Continuing with the analysis, the second example of this set (Figure 2, No. 11) provides an elegant symmetrical melody, beginning and ending on the A below middle $\mathrm{C}$, with a rise-fall-rise pattern in the middle. The words read no pěkne by to bylo [well that would be lovely]. [30] The primary accent falls on pěkne [lovely]. This judgment is based on the pitch movement (rise of a P5) and by the lengthening (in this case realized as a quarter note following an eighth). Additionally, Janáček marks the two syllables of this word with tenuto markings. Overall, the contour would best be described as falling. The pitch movement on by [would] should likely be discounted, as it is lexical in nature, rather than affective. Because the contour appears as a coherent whole, and because there are no changes in tempo (thus no lengthening or anacrusis) after the initial eighth-quarter relationship, it were best to consider this a single intonation unit.

\section{Rise-Fall and the Tonality of Speech: a Bartoš Set}

The following four examples (Figure 3) are from what Janáček termed sada Bartoš [a Bartoš set]. The page Z20 (6) is dated at the top 19 September 1897. František Bartoš (1837-1906) was a longtime companion and friend of Janáček's. They were friends from at least 1886, when Janáček began as a voice teacher at the Brno Old Gymnasium, where Bartoš had taught since 1869, later becoming the school's director (Drlíková, 2004, pp. 38-39). [31] Bartoš and Janáček would go on to publish collections of Moravian folks songs in 1890 and 1899-1901. Bartoš is known both for his conservative efforts to establish and preserve a standard for the Czech language, and for his bolder work to compile a description of the region's various dialects. 


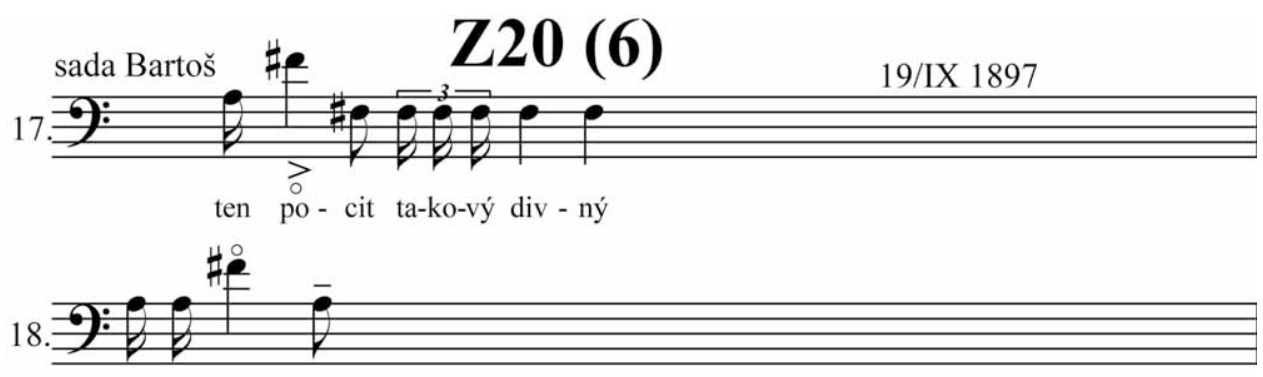

to je hroz - né

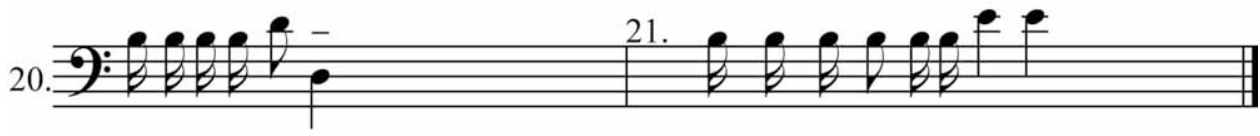

to tr-va-lo po-řád

jak sme vy-stou-pi-li z lódi

(vykládal živě o své cestě do Stokholmu)

Fig. 3. A Bartoš set. (Use the following link to download the audio file for this example: https://kb.osu.edu/dspace/bitstream/1811/24010/3/EMR000009a-Eaves03.ogg)

The first of these speech melodies (Figure 3, No. 17) reads: ten pocit takový divný [this sensation (is/was) rather strange]. The contour is best described as a rise-fall. The primary accent falls on the second word pocit [sensation], based on the dramatic pitch movements, and the notation of an accent mark on the second note, as well as the agogic accent caused by a four-fold increase in duration for the second note. There is a rise of a M6 from the opening sixteenth note on the top line A of the bass clef, for the word ten [this], to a quarter note on the F\# above for the syllable po-, followed by a drop of an octave to the F\# below, on the syllable -cit. The remainder of the utterance rests entirely on this F\#, three triplet-sixteenths for the word takový [rather] and two quarter notes for the final word divný [strange].

Most likely this should be considered one coherent intonation unit, though a possible argument exists to separate off the final two words, citing anacrusis (the three triplet-sixteenths). However, the continuation from -cit through the end on the same pitch, and the simple explanation of lexically based rhythm for the word takový, both argue for a single unit. Musically, this sounds very much like one coherent phrase, with F\#-minor tonal implications. In this interpretation, the eighth and triplet-sixteenths can be heard merely as momentary contrast to emphasize the slowing to even quarter notes at the end of the phrase. It should be pointed out that although the spelling (and presumably "proper" speech) calls for elongation of the final vowels for both takový and divný, Janáček notates these syllables as the same lengths as the remaining syllables within each of these words. Such vowel length is theoretically significant, and an important factor in disambiguating meaning, since the corresponding homophonic words with short vowel lengths, in many cases, produce adverbs rather than adjectives. In the particular cases of takový and divný, however, such adverbial forms would be unusual and non-standard language. [32]

From this one example, it remains an open and testable question whether vowel length is routinely distinguished in spontaneous speech in general, or perhaps only in cases where disambiguation of this sort is most useful. For instance, the context of an utterance may make clear the meaning, and thus render such disambiguation redundant in practice. One other point to be made however is that despite the writing of equal durations, it is quite possible that this sort of notation serves as conventionalized shorthand for actual performances which are routinely realized with durations of varying lengths. There is some preliminary evidence to support this idea, that for instance triplet-eighth notes in performance are not of equal length, though from habit or convention this notation suffices both for the performer, and as a reflection of a listener's perception, but not as an accurate record of the performed durations. [33] If this is the largely tacit assumption of music notation and practice, there is no reason for it not to be extended to the transcription of speech, and assumedly as a reflection of speech perception, though it may veer in as-yetundefined though likely consistent ways from instrumentally precise measures.

The second example in this group (Figure 3, No. 18) is to je hrozné [that is horrible]. The primary accent lies on hrozné as would be suspected from the fact that it is the only word in the utterance to present meaningful information. A clear pitch accent as well as agogic accent are realized on the syllable hroz-, 
which follows the same pattern as the example above, namely a rise from the topline A of the bass clef to the F\# a M6 above. The rhythm (as dictated principally by the number of syllables preceding the accent) is two sixteenth notes, followed as above by a quarter on the F\#, then falling once again, but this time to the opening pitch of A, again for the duration of an eighth note. Taken together, this presents another example of rise-fall intonation. Janáček marks the F\# in this case, not with an accent mark, but with what appears to be the articulation mark used for stringed instruments to indicate an open string. [34] It's possible that this "open string" marking was intended as a staccato, but it is difficult to sustain that, since he was quite capable of marking a small dot for staccato as he did elsewhere, even on this same page of his notebook. While it is difficult to ascertain precisely what the composer intended here, one speculation is that he wished to indicate that the sound was particularly clear and resonant, like a bowed open string on a viol. Considering the normal speaking range of an average adult male, this $\mathrm{F} \#$ above middle $\mathrm{C}$ would sound quite high. Even for a trained tenor, such a leap up to this register in speech would be dramatic, bordering on exaggerated.

The following eighth note on the syllable -né is marked with a tenuto sign. As above, the adjective contains a final long vowel in spelling, although its note value is written longer than the initial unaccented syllables of the anacrusis, yet shorter than the accented syllable preceding it. Interestingly however the tenuto marking is used here. It is as if to acknowledge that this syllable was perceived as long, despite the fact that the accented syllable preceding it sounded longer. In part this may be due not only to the prominence of hroz-, but additionally the result of its containing three consonants. The length of a syllable cannot be entirely determined by its vowel, but must also accommodate the articulation of all its sounds. [35]

The third example from this Bartoš set (Figure 3, No. 20) is to trvalo pořád [it lasted forever]. [36] Rhythmically this is the cleanest example of the three in terms of the evidence of anacrusis at the beginning and lengthening at the end. The first four syllables are expressed in sixteenth notes all on the pitch B below middle C, followed by an eighth, with a pitch movement up to D, then by a drop of an octave to the midline $\mathrm{D}$ of the bass clef. Janáček places a tenuto mark above this final syllable. Clearly then the primary accent falls on the word pořád, and the contour is best described here, as with the two preceding nápěvky, as risefall.

These three together present a small case study of one speaker's realization of the rise-fall contour. In the first two cases, the rise is virtually the same, with the only change being the number of syllables preceding the pitch movement. The fall differs in these first two, with the first dropping below the opening pitch level, and the second falling level with it. Musically, the first (Figure 3, No. 17) sounds fully resolved to the tonic (with the implication as noted above of F\#-minor). The second (Figure 3, No. 18) sounds somewhat resolved, but with the implication of continuation. Prosodically, I would argue the same holds. In any case, these two sound very much alike, and could easily be considered variations of one another.

The third example in this set (Figure 3, No. 20), while also representing a rise-fall contour, sounds more different from the first two than they do from each other. The rise is narrower, a M3 rather than a M6. The fall of an octave at the end corresponds to that of the first example, yet in this case the harmonic implication is ambiguous, perhaps that of G-major, thus this final note is on the dominant rather than the tonic. But $\mathrm{G}$ is not sounded at all. Musically at least this sounds like a half cadence, albeit a rather emphatic one. Looking to the final example, which is connected contextually, and possibly followed immediately upon this one, more is revealed. The shape of this last (Figure 3, No. 21) is simply a rise, and in this way differs from the previous three. Jak sme vystoupili z lodí [how we disembarked the ship] seems to continue the thought from the previous nápěvek. Thus, what lasted forever was the disembarkment. Again, we have a firm example of anacrusis at the beginning of the phrase, with lengthening at the end. The whole begins with three sixteenth notes, an eighth, then two more sixteenths, capped by two quarter notes at the end. The first six notes are intoned on the pitch $\mathrm{B}$ below middle $\mathrm{C}$, with the last two on the $\mathrm{E}$ above.

Taken together, these two examples (Figure 3, Nos. 20 \& 21) might imply, rather than G-major, the tonality of E-minor, with a lowered seventh scale degree. But a mere three notes are given: B, D, and E. In light of Janáček's description of lively narration, and a recognition of the exaggerated, but seemingly good-hearted nature of these examples, one might prefer to hear these last two as pentatonic, with the G and $\mathrm{A}$ of the scale remaining silent. Looking back then to the first two examples, it is possible to contend that both are unresolved in a sense, and that rather than an F\#-minor tonic, the implication is D-major.

These examples raise the question as to whether we can derive a sort of tonality (though probably of a transient sort, like the momentary tonal shifts within the development section of classical-era sonata allegro form) from stretches of speech by an individual, or even possibly from two or more participants in a 
conversation. It has been assumed that tonality really has no place in linguistic analysis (Christiansen 2002, pp. 108-109; 't Hart, Collier, \& Cohen 1990, p. 21), but this has not been empirically established. Encouragingly however, there is some evidence of pitch stability in production for both tonal and non-tonal languages as well as for music. Experiments have been done that show individuals reproducing, with the same or nearly the same pitches, both songs and spoken utterances (when asked to produce the same example), even across the lapse of a day or week (Ladd, D., 1996, pp. 64-66; Deutsch, D. et al., 2004; Levitin, D., 1994). [37]

\section{Hesitation}

Z20 page 12 presents two unrelated speech melodies, but a good deal of contextual information. The first (Figure 4), which I will describe here, is dated 18 November 1897, presenting us the scene of an old woman at the butcher's. Já ty paznehty nemám ráda [I don't like those hooves] she says. Janáček provides the following background: Žena stará - nechtěla asi koupit si "nožičky" u řezniku - mluví k druhé $\check{z}$ eně - zvolna - klidně [An old woman - it seems she didn't want to purchase "little feet" at the butcher's she speaks to a second woman - slowly - calmly].

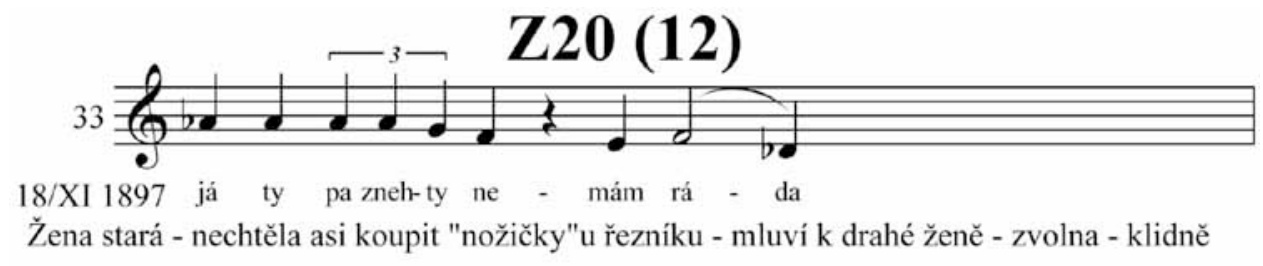

Fig. 4. Hooves. (Use the following link to download the audio file for this example: https://kb.osu.edu/dspace/bitstream/1811/24010/4/EMR000009a-Eaves04.ogg)

The words and the picture he paints in themselves provide ample fodder for a dramatist. The notation adds another dimension. Musically, we have a wonderful melancholic, sentimental melody, starting on the $\mathrm{A} b$ above middle $\mathrm{C}$, descending in a mostly stepwise descent toward $\mathrm{D} b$. Quarter notes predominate, except the three syllables of paznehty [hooves] are given triplet-eighths-likely motivated by the natural rhythm of the three-syllable word (like takový above) - and the first syllable of ráda [like] is given a half note. [38] The stepwise descent is only broken on the first syllable of ráda, which reverses course stepwise upward, followed by the only leap, a descent of a M3 to the final note, connected to the preceding F with a slur. With the reversal of direction, the agogic accent, and its containing the only leap of the melody, this word is set off as most prominent. The melancholy of this melody is effected by the unusual scale defined by half steps from $\mathrm{A} b$ to $\mathrm{G}$ and from $\mathrm{F}$ to $\mathrm{E}$, and the augmented $2^{\text {nd }}$ from $\mathrm{E}$ down to $\mathrm{D} b$.

Rhythmically, there isn't any real indication of initial anacrusis, though the half note toward the end can surely be viewed as lengthening. The persistent descent leads us to suppose this is a coherent single unit. But Janáček marks a quarter note rest in the middle of the word nemám. The word itself consists of two parts: the privative ne- and the conjugated verb mám. It is remarkable both that the old woman made a pause in the middle of the word - though coming as it does between the affix and the verb proper it would seem not so uncommon-and also that the composer observed this feature and sought to record it. What led to her hesitation can only be speculated. Was there some distraction that Janáček was unaware of, or simply didn't capture in his transcribing? Did she pause to think of just the right word-a rather funny thought, since the phrase she completes is perfectly commonplace? We will never know, but it demonstrates the sensitivity of the transcriber, and is a tribute to his skill in observing natural data.

Another example of hesitation (Figure 5) is presented on Z20 (44). The speaker utters dněskaj - je dobře [today is good]. [39] The speaker is depicted: Tluče kameni muž [a man is breaking stones]. The melody at the top of a bass clef is G-G-F-G-E $b$. The rhythm indicates the hesitance, though here with a filled pause rather than a rest, as was seen in the previous case. Janáček writes a quarter note, then a half note, followed by three triplet-eighths barred together, one note per syllable throughout. The anacrusis/lengthening paradigm is reversed, with the greater lengths at the beginning and anacrusis at the end. 


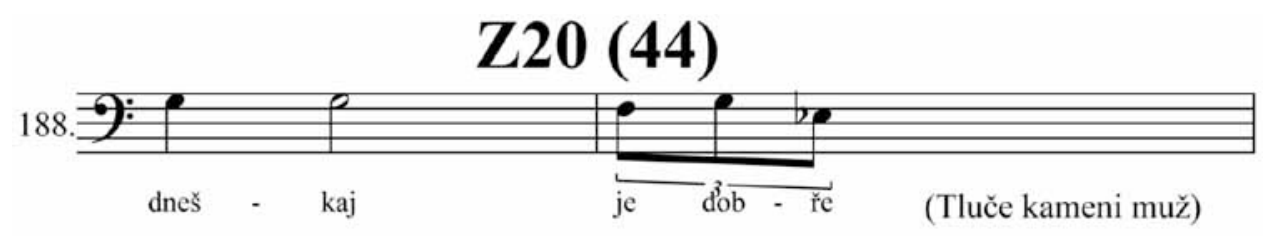

Fig. 5. A man breaking stones. (Use the following link to download the audio file for this example: https://kb.osu.edu/dspace/bitstream/1811/24010/5/EMR000009a-Eaves05.ogg)

The half note on -kaj serves to allow the speaker some time to formulate his thoughts. Again, as in the previous example, the end result is perfectly commonplace, yet the implication to a listener is that there is more beneath the surface - a sense either that the man wishes us to know that other days have not been so good, or possibly that the words themselves, under the circumstances, are not to be believed. Why he is breaking stones, we are left to wonder. [40]

\section{Laughter Notated}

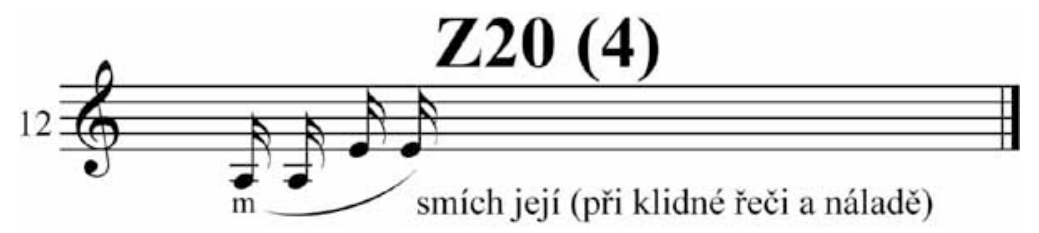

Fig. 6. Her laugh. (Use the following link to download the audio file for this example: https://kb.osu.edu/dspace/bitstream/1811/24010/6/EMR000009a-Eaves06.ogg)

Revisiting Z20 page 4 (Figure 6), we have an example not of words, but of a notated laugh. There are four pulses of laughter described, all on the vocable $m$. Their melody is simple: two pulses on A below middle $\mathrm{C}$, followed by two on the $\mathrm{E}$ above. All are tied together with a slur. Following this notation on the staff, Janáček wrote smích její [her laugh], then in parentheses při klidné řeči a náladě [during calm speech and cheerfully].

Of the selections on the following page, Z20 (5), the first three are non-verbal, and the last is plain text, unnotated. The first two are laughs; the third is the clucking hen described below. The first laugh (Figure 7, No. 15) is specified as that of sl. Zd. Klnerová [Miss Zdenka Klnerová]. The syllable is written as $h a$, repeated four times: three sixteenth note Eb's at the top of the treble staff, falling to the A tritone below, marked as a staccato eighth note.

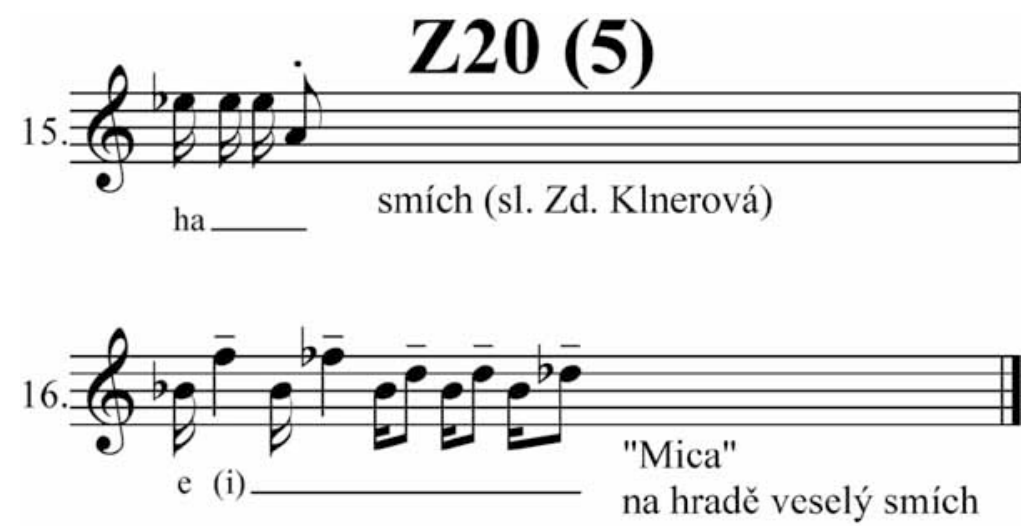

Fig. 7. More laughter. (Use the following link to download the audio file for this example: https://kb.osu.edu/dspace/bitstream/1811/24010/7/EMR000009a-Eaves07.ogg)

The second of these laughs (Figure 7, No. 16) is rather complex in several ways. Rhythmically and 
melodically it can be broken into two sections. The first is a sixteenth on $\mathrm{B} b$ in the middle of the staff, rising to the $\mathrm{F}$ above, written as a quarter note; this is repeated, with the exception that the second note becomes an Fb. In both cases, the quarter note is given a tenuto marking. The second section of the laugh is a series of three barred sixteenth-eighth units, $\mathrm{B} b-\mathrm{D} \mathrm{B} b-\mathrm{D} \mathrm{B} b-\mathrm{D} b$, with the second of each group given a tenuto marking. The laugher is identified merely as "Mica", with the description na hradě veselý smích [at the castle jolly laughter].

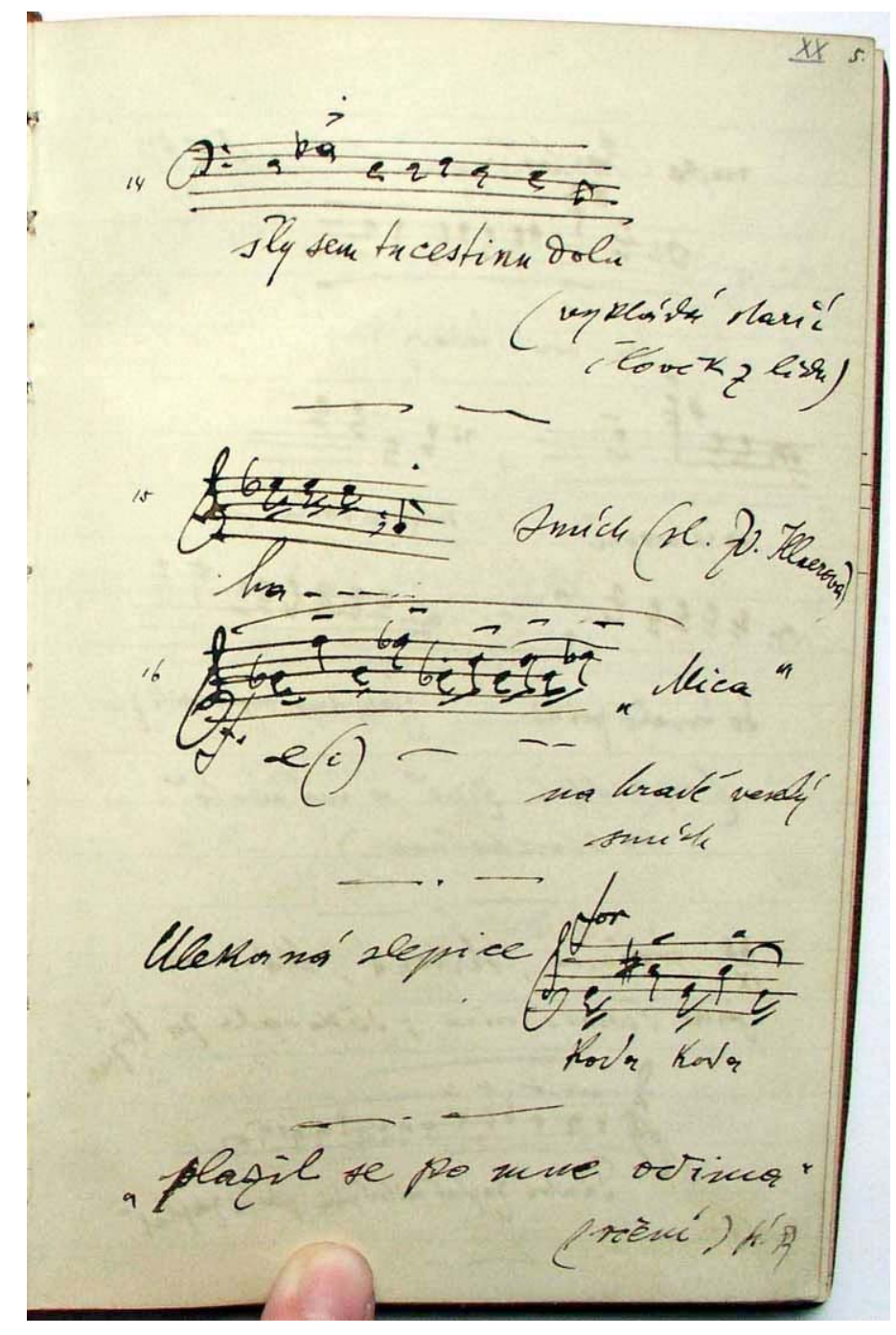

Fig. 8. Z20 (5) in Janáček's hand.

At the bottom of this page (see Figure 8), Janáček has written a plazil se po mne očima (rčení) p. B [and he crept around me with his eyes (a saying) Mr. B]. [41] It is interesting to observe what things caught the ear of the composer. At times, he notates what on the surface appear to be unremarkable events, as for example the nearly monotone bylo to pravda nebo nebylo to pravda above (Figure 2, No. 10); on other occasions, he chooses seemingly arbitrarily to notate part of an utterance in score, and the remainder merely as text, or as here, simply the text. Janáček explained that in concentrating on the melody and rhythm of speech, he quite often lost the words (Straková \& Drlíková, 2003, p. 616). Yet, we have reasons to not take him at his word in this. While there were a few times when he notated melodies without their text, they are extremely rare. And though he may have found the underlying prosody more interesting than the words in many cases, here we have an example where the words stand on their own, thus were deemed by Janáček as worthy in themselves of being preserved, absent their prosody. 


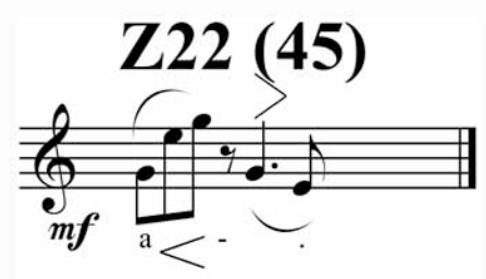

L. směje se radostně

Fig. 9. Lidka, delightedly. (Use the following link to download the audio file for this example: https://kb.osu.edu/dspace/bitstream/1811/24010/8/EMR000009a-Eaves09.ogg)

In 1901, page 45 of notebook 22, we hear the fluid laugh of a child, perhaps his young neighbor Lidka from Hukvaldy. The entire laugh occurs on the vocable $a$, encompassing a melody of three barred and slurred eighth notes on G4-E5-G5, some sort of mark that looks in Janáček's hand like a "C" appears in mid-staff, possibly an eighth or quarter rest, followed by a dotted quarter note slurred to an eighth, on the notes G4-E4. Below the first cluster of three is marked a crescendo, and above the second cluster of two notes he has written a decrescendo. The entire staff is marked $m f$. Below the staff is the description: $L$. směje se radostně [L. laughs delightedly].

\section{Roosters, Hens, and Other Birds}

\section{Z20 (3)}

Kohouti druzlica kol mého bytu pod Hukvaldy
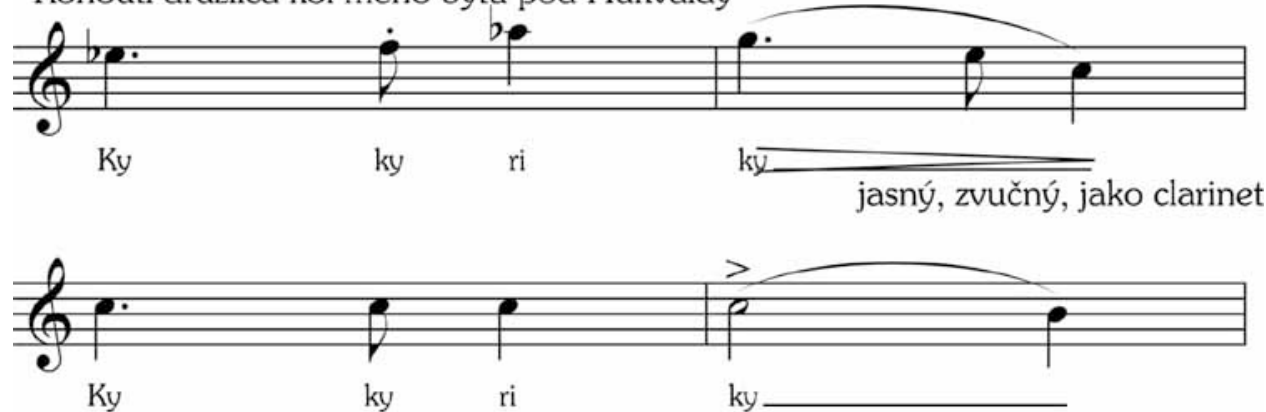

jako ang. roh.

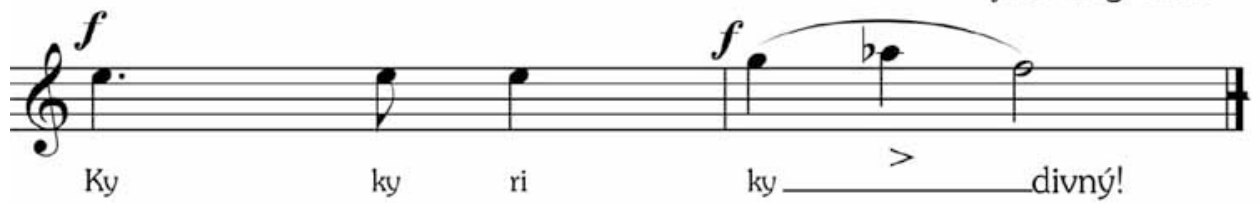

Fig. 10. Kykyriky. (Use the following link to download the audio file for this example: https://kb.osu.edu/dspace/bitstream/1811/24010/9/EMR000009a-Eaves10.ogg)

Here Janáček turns his ear to other sounds of nature. Many composers have been known to borrow motives from bird call. Though we have no evidence of these calls in Janáček's compositions, they provide us a case study of his observations. In the first of these, Z20 (3) (Figure 10), he notates the calls of roosters, heard near his flat in Pod Hukvaldy. By the ears of most Europeans, roosters call "ky-ky-ri-ky" where Americans hear "cock-a-doodle-doo". Janáček simply chooses to go beyond onomatopoeia, to specify pitches and rhythm. Unlike in most of his speech transcriptions, Janáček has no qualms about notating several pitches for the last "syllable" of the rooster's call. For the most part, the rhythm and the melodic contours are consistent. In each of the three examples, the rhythmic pattern begins with a dotted quartereighth-quarter (after which he draws a barline), followed by a varying rhythmic pattern for the closing syllable. The melodic shape for all three conforms to what is best described as a falling contour, or perhaps 
a rise-fall.

The first and last both move up from the opening pitch, then fall at the end. The second example is nearly monotone, on a pitch of $\mathrm{C}$ above middle $\mathrm{C}$, with only a slight fall to $\mathrm{B}$ at the end. He has written a description for each as well. The first is marked jasný, zvučný, jako clarinet [clear, resonant, like a clarinet]; the second he describes as jako ang. roh. [like an English horn]; the third, as Janáček remarks, is divny! [strange!]. This strangeness is exhibited in the pitch movement on the final syllable, G-A $b-\mathrm{F}$, in the rhythm quarter-quarter-half. The rise in pitch from the first note of $-k y$ is what appears oddest. To make this clear, Janáček writes an accent mark under the $\mathrm{A} b$.

On page 5, we meet klekaná slepice [a kneeling hen] clucking away, who as one might suspect, calls out Koda koda. The entire nápěvek is given the marking of forte. The first koda is written as a sixteenth followed by a quarter, on the notes G4-C\#5, with the C\# given a tenuto marking. The second

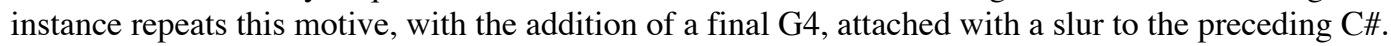

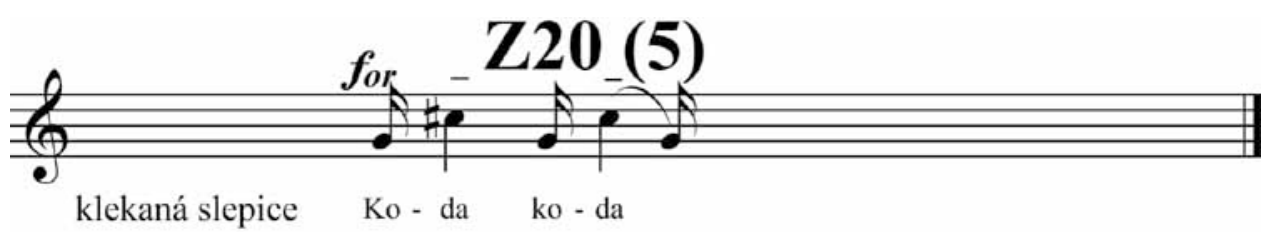

Fig. 11. A kneeling hen. (Use the following link to download the audio file for this example: https://kb.osu.edu/dspace/bitstream/1811/24010/10/EMR000009a-Eaves11.ogg)

Looking forward to page 36, Janáček has recorded the call of some nameless bird, five sixteenth notes on B6, rising to two quarter notes on the $\mathrm{C} \#$ above. He has written the sounds as t'a t'a ... $-a$. [42] The entire sequence is marked forte. Beneath this, in parentheses, he has described jakýsi ptáček mnohokrát to opakoval [some kind of little bird repeated this many times].

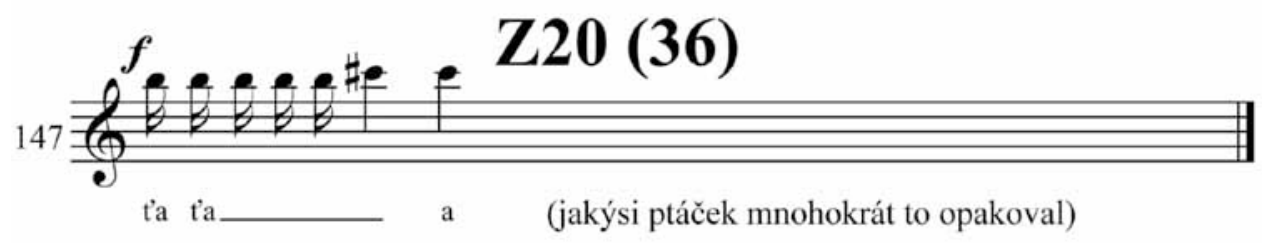

Fig. 12. Some kind of little bird. (Use the following link to download the audio file for this example: https://kb.osu.edu/dspace/bitstream/1811/24010/11/EMR000009a-Eaves12.ogg)

\section{Leavetaking}

On several occasions, Janáček latched onto a single phrase, sometimes within a concentrated study collected together at one point in his notebooks, or as in the immediate case, over the course of several utterances recorded at different times. One example of this sort is the phrase s pánem Bohem, [goodbye; literally "with lord God"]. One would suspect from the great many notated examples of this phrase in his notebooks, and several variations, that it was a common expression in his day, or within the sorts of social networks he found himself traveling. [43] We will look at a couple of these here. The first (Figure 12) appears from 1897, Z20 page 13. The speaker is identified as moje mlékařka [my milkmaid]. The staff is marked $m f$, with the first note, on the syllable $s$ pá- set off with an accent mark. [44] The first and last two syllables are given quarter note durations, with an eighth given to the second note: B3-C4-A3-A3.

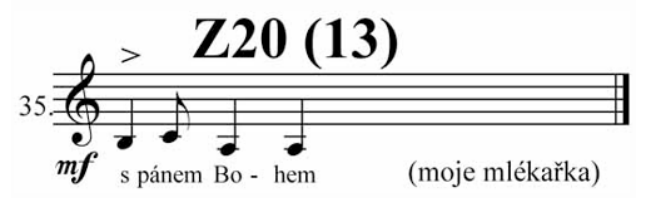

Fig. 13. My milkmaid's goodbye. (Use the following link to download the audio file for this example: https://kb.osu.edu/dspace/bitstream/1811/24010/12/EMR000009a-Eaves13.ogg) 
Z20 (15), dated at the bottom of the page (following several other nápěvky) 31 December 1897, presents a second example. No dynamic marking is noted. The opening rhythm is once again a quarter followed by an eighth, but these two are slurred together, and specified as a triplet rhythm, followed by two eighth notes. No accent is marked, but a decrescendo is, for the first two notes: A4-C4, followed by two B's just below middle $\mathrm{C}$ on Bohem. The contour is essentially the same as the first example above, rising slightly to the second note, then falling. In the first case, the opening interval is a $\mathrm{m} 2$, followed by a fall of a 33 . The same intervals are used here, but their order is reversed.

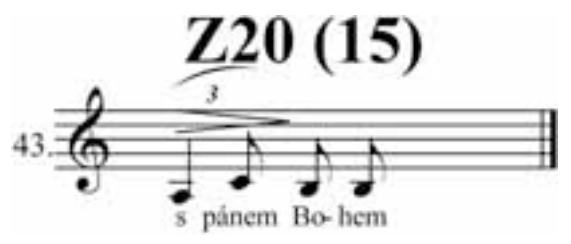

Fig. 14. Another goodbye. (Use the following link to download the audio file for this example: https://kb.osu.edu/dspace/bitstream/1811/24010/13/EMR000009a-Eaves14.ogg)

It is difficult to separate out the musical sense from the linguistic, in describing these two examples, out of their original context, which is not preserved. Harmonically, the implication of the first is stronger, giving a sense of A-minor, thus a rather emphatic conclusion to the motive. Prosodically, then this example would seem to show a final contour. Whereas in the second case, with weaker tonal implications, and the smaller pitch interval at the end, especially as it is a descending semitone, we hear a more ambiguous, but likely continuing contour. How do these ideas play out in the linguistic literature?

Du Bois and colleagues (1993) address these matters concisely:

When a speaker arrives at the end of an intonation unit, poised to continue on to the next-or not continue - the intonation contour usually gives a fairly clear indication of whether the discourse business at hand will be continued or has finished (p. 53).

They refer to "a class of intonation contours whose transitional continuity is regularly understood as final in a given language," declaring that "[f]or English and many other languages, this means primarily (but not exclusively) a fall to a low pitch at the end of an intonation unit." (p. 54) They go on to describe continuing contour:

The contour is often realized in English as a slight rise in pitch at the end of an intonation unit (beginning from a low or mid level), but it may have other realizations as well, each of which presumably has slightly different pragmatic implications. One type of continuing contour is realized by a terminal pitch that remains level; another, by a terminal pitch that falls slightly, but not low enough to be considered final (p. 54).

These concepts of continuation vs. finality can be well correlated to the musical ideas of conflict and resolution. A melodically descending semitone is far more indicative of something yet to come than is a descending $\mathrm{m} 3$. Prosodically, we might theorize that a narrowing of intervals toward the end of an utterance begets a greater sense of continuity, or inversely a weaker sense of finality. Assuming this last proposition then, at least in regard to these two examples, we have a concord between the musical and the prosodic. One might suppose in the first example from Z20 (13) that the speaker is responding to the leavetaking of an interlocutor, whereas in the latter example from Z20 (15), this speaker initiates the leavetaking, and thus expects a response in kind.

A fleeting moment preserved from the $17^{\text {th }}$ of January 1914 (Figure 14), Z41 (3), shows the sensitivity Janáček brought to his daily affairs. One even suspects a bit of oversensitivity in regard to his relations with his wife, in the degree of detail that he preserved. Tak ja už du! [45] [Okay I'm going now!] says Žena moje [my wife]. $M f$ he writes, a staccato for the opening pitch, two tenutos, and a caretted accent mark for the last. Sixteenth-quarter-quarter-quarter is the rhythm. Further, he notes the entirety is spoken in 
hlavový registr [head voice]. The melody, a rising major third, sounding like one of the Correllis' trumpet calls: B-B-B-D\#, Zdenka's triumphant declaration of imminent departure.

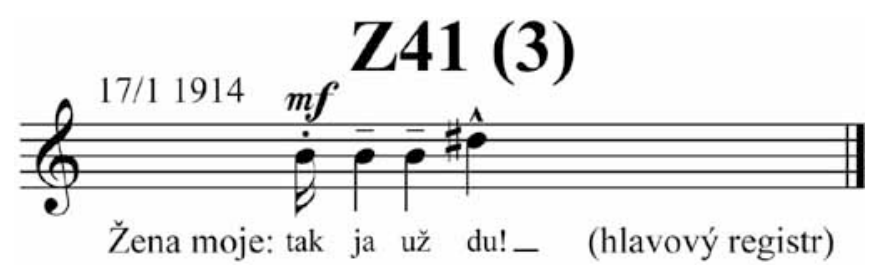

Fig. 15. My wife. (Use the following link to download the audio file for this example: https://kb.osu.edu/dspace/bitstream/1811/24010/14/EMR000009a-Eaves15.ogg)

Is this the record of her actual performance, or rather his impression, overly dramatic, affected. Musically, such a phrase would beg completion, a drop back down to the tonic perhaps. Prosodically, it comes across as odd. The register is high (and as he noted uttered in head voice). The simple rise contour often implies interrogation, a yes/no question, rather than a declarative statement. An expected contour in this context might be a slight rise, with some lengthening on $u \check{z}$, falling again slightly on the final word $j d u$. The primary accent would be expected on $u \check{z}$, serving the same adverbial function as the word "now" in the English gloss.

A less emphatic version of this statement might be simply $u \check{z} j d u$, corresponding to [I'm going], where the primary accent would rest emphatically on the verb. In example 22, the addition of tak [so] and the personal pronoun $j a ́$ [I] both serve to add emphasis to the expression (in part simply by adding more syllables to the phrase). [46] A musical equivalent to this would be adding repeated notes within a melody to render it more emphatic, as in a fanfare. Nonetheless, this particular linguistic expression is perfectly commonplace. Janáček's attention to details brings sharper focus to it, in the way that a close-up photo of a dandelion or a housefly might render these common objects something more interesting to observe.

9:45 in the evening, on July 18, 1917, Z48 (31), Janáček depicted the departure of Anděl žena [an angel woman] (Figure 15). Už du dobrou noc [I'm going now good night], a marked contrast to his wife Zdenka's motive above (Figure 14). The five even quarter notes are contained by a slur; $m f$ marks the utterance, mostly just below middle C: B-A-D-B-A. In these marching steps, one hears a faint reminder of Mussorgsky's promenade through the exhibition from 1874, nearly wishing the melody to continue its imitation with two eighths and a quarter; E-A-F\#. Did Janáček hear such musical similarities? One can hardly help but suspect that he did, and that indeed such phenomena were part of his motivation in gathering these speech melodies.

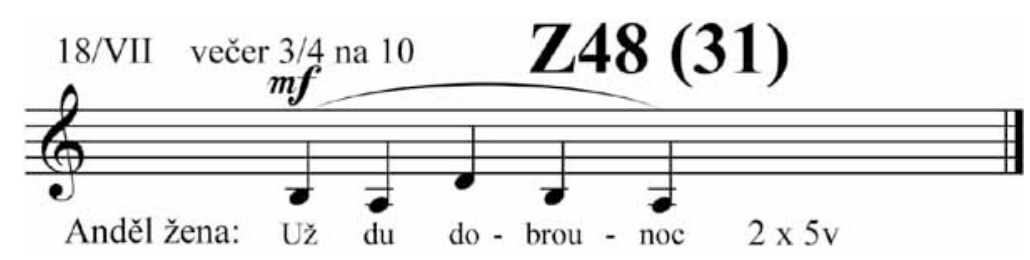

Fig. 16. An angel departs. (Use the following link to download the audio file for this example: https://kb.osu.edu/dspace/bitstream/1811/24010/15/EMR000009a-Eaves16.ogg)

Prosodically, this example presents one or two intonation units. To counter the possibility that a break be heard between $d u$ and dobrou, the music provides a slur to tell us this is a single phrase. In order to contend for two however, one might argue for the existence of pitch reset. At the level of precision that Janáček provides, however, we would need to consider the B and D as functionally equivalent. Experimental evidence would be needed to support this sort of supposition. Some linguistic notational practices however would simply avoid a dilemma of this sort; Merely considering high and low pitch, we could lump the B's and D together, or the B's and A's. I would counter however that much of the richness that is inherent to the melodies of speech are thereby covered up, thus arguing in favor of the type of transcriptional practice that Janáček followed. 


\section{Street Cries \& Imperatives}

The unselfconscious calls of people in the street, provided ample fodder for Janáček's pen. In 1897, Z20 (13), he records 18 letý uličník - volá za holkou [18 year old street urchin - calls to a girl] (Figure 16). Pak pojd’ když tě volám [Then come when I call]. The nápěvek is marked lehce [lightly] with a dynamic mark of $m f$. There are two brief intonation units represented. The first consists of the opening two words, set to three notes, F4-A4-F5, quarter-eighth-thirtysecond, followed by a dotted sixteenth rest, and a barline struck in the staff. The two notes accompanying pojd' [come] are slurred and beamed. A tenuto is marked for Pak [then]; [47] and an accent mark attends the A. The second motive steps along in even eighth notes, all resting on the bottom space $\mathrm{F}$.

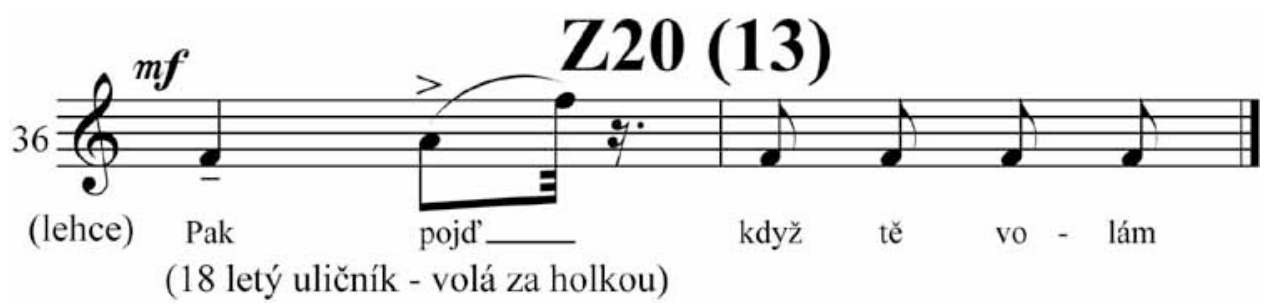

Fig. 17. A street urchin. (Use the following link to download the audio file for this example: https://kb.osu.edu/dspace/bitstream/1811/24010/16/EMR000009a-Eaves17.ogg)

The wide rise contour of the first intonation unit corresponds appropriately to the command implicit in the words. The initial F sets the baseline; the leap of a M3, followed by a larger leap of a m6 are heard as imperative. Movement within a single syllable, especially of this width, is rare in the transcriptions; this indicates that Janáček heard something significant here - that the prosodic meaning resided in this movement. The intervening rest, followed by four unaccented level pitches, gives the sense that these words were uttered with less import than the command itself, or perhaps were intended as conciliatory.

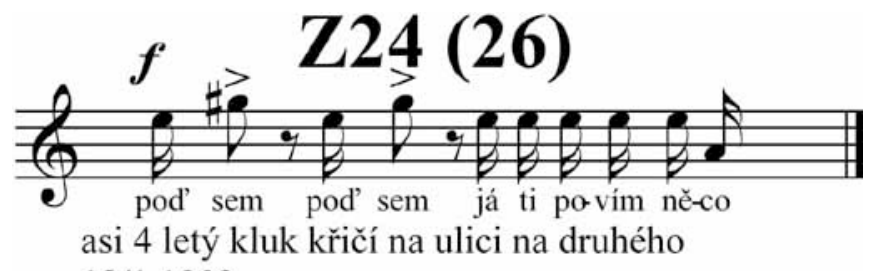

18/1 1902

Fig. 18. I want to tell you something. (Use the following link to download the audio file for this example: https://kb.osu.edu/dspace/bitstream/1811/24010/17/EMR000009a-Eaves18.ogg)

Children sometimes partake in the occasional commanding cry in the streets as well. On the $18^{\text {th }}$ of January 1902, Z24 (26), Janáček listens as asi 4 letý kluk křičí na ulici na druhého [a boy about four years old shouts in the street to a second]: pod' sem pod' sem já ti povím něco [come here come here I want to tell you something] (Figure 17). [48] Marked $f$ at the start, youthful eagerness and energy comes through, as in the last example. The overall pitch is high, and the pace is quick. Three intonation units are set apart by eighth note rests. Sixteenth-eighth, sixteenth-eighth, comes the opening repetition; six sixteenth notes proceed. The eighths of each of the first two units are given accent marks. Harmonically, we have the dominant defined, E5-G\#5, E-G(\#), then five E's, and a drop on the last note to A4, the tonic. Prosodically, we have a high-rise contour for the repeated imperatives, then a strong final contour, a drop of a fifth to the lowest pitch of the utterance. In all cases, the baseline pitch is $\mathrm{E}$, which begins each intonation unit. The 
lack of final lengthening for the last part, with its accompanying fall, has not the effect of incompleteness, but rather one of impatience.

Another scream of the same sort (Figure 18) was recorded 8 August 1915, Z45 (4), somewhere in Hukvaldy. Děcko křičí zdálky na matku [A child screams from a distance to mother]: Ja vam cosi ukážu! [I want to show you something!]. [49] The utterance is marked $f$, set with a treble clef, and sits almost entirely on the $\mathrm{G}$ above the staff, with the exception only of the final note, a m6 below, on the midline B. All notes are quarters, save the penultimate, a half note, set off as well with an accent mark. As we have seen before, each syllable is given a single note.

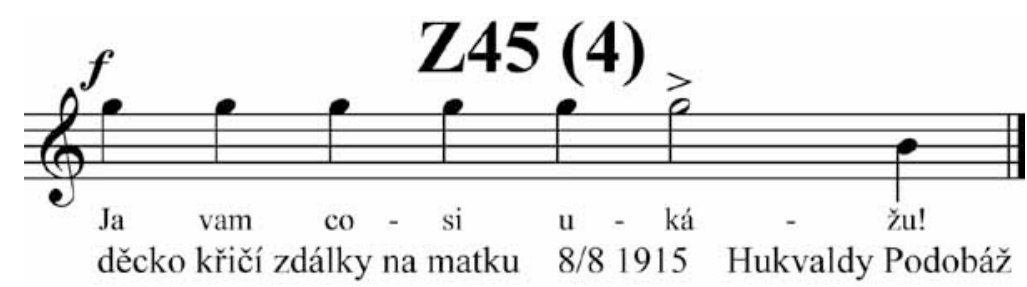

Fig. 19. I want to show you something. (Use the following link to download the audio file for this example: https://kb.osu.edu/dspace/bitstream/1811/24010/18/EMR000009a-Eaves19.ogg)

The even movement, pitch high in the register, with the only lengthening corresponding to the primary accent, along with his marking of $f$, and his description of a scream from a distance, give us the sense indeed of a child deliberately calling out, with measured steps, to be heard. Because the pitch opens already quite high, there is no room for an upward pitch accent, which might otherwise occur. Additionally, the drop of a $\mathrm{m} 6$ at the end seems indeterminate. The drop could have been a fifth, an octave, even a ninth without changing the essence.

An entirely different sort of public call appears in notebook Z48, straddling pages 13 \& 14 (figure 19). Dated 11 July, the year is most likely 1917 . Described as ráno $z$ balkonu [morning from the balcony] a nameless ona [she] calls out, mírně [meekly]: Moja toaleta netrvá dlouho [My toilet doesn't last for long]. [50] Despite the mundaneness of the expression, and perhaps the inappropriateness of calling such a thing out in public, Janáček is nonetheless able to amuse himself in capturing a rhythm and melody worthy of note.

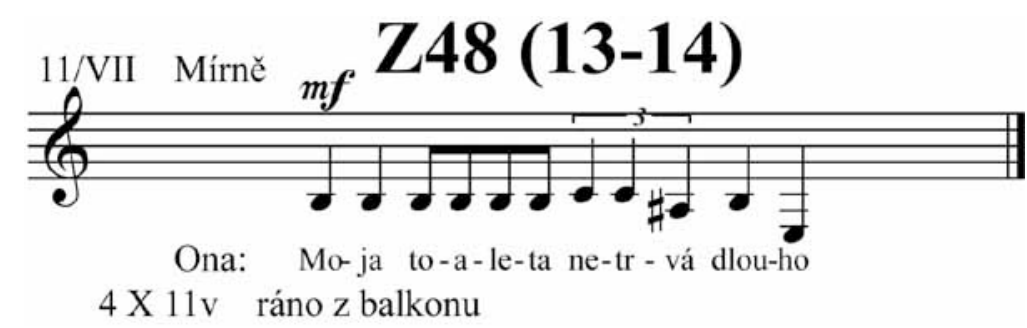

Fig. 20. My toilet doesn't last long. (Use the following link to download the audio file for this example: https://kb.osu.edu/dspace/bitstream/1811/24010/19/EMR000009a-Eaves20.ogg)

One of the more complex rhythms that he captured, it opens with two quarter notes, followed by four eighths, three triplet-quarters, and finally two more quarter notes. The register is quite low, and gives the impression of a contralto or a heavy smoker. The range of a $\mathrm{m} 6$ peaks only at middle $\mathrm{C}$ and plunges to E3 below. The tonality is E, though no indication is given as to major or minor. A secondary leading tone, $\mathrm{A}$, sets up the final descent of $\mathrm{B}$ to $\mathrm{E}$ for the final two pitches, strengthening the sense of key. The melody is B-B-B-B-B-B-C-C-A\#-B-E, one of the most purely musical of the motives he presents in the nápervky, rather severe in the predominance of semitone motion, lacking any movement by third, and closing with a hollow open fifth descent. It is also the sort of melody that one would never expect in Janáček's own compositions. One can almost hear the composer's chuckle as he contemplates the operatic writing of some of his predecessors and contemporaries, with a sneer, imposing these words on their overly self-conscious, melodramatic style: my toilet doesn't last for long. 
Next, we see one of several motives that Janáček recorded of sausage vendors on the streets (Figure 20). Nine o'clock at night, the 7 of October 1927, Z66 (150), in the town of Tábor, he hears: Horké parky [Hot dogs]. Again, the degree of detail that he captures is quite impressive. Written on a treble staff, marked $s f p$, with a decrescendo covering the last three notes, and accents on the final two, he records a dotted-quarter, a sixteenth, then two eighths. The melody is G5-A5-A5-A5. Below he has noted polo $g$ polo fis! [half $\mathrm{G}$ half $\mathrm{F}$ !] What is most revealing about this transcription is how certain he was of the tonal implications of the speech melody, mere isolated notes, but to him enmeshed within an undeniably musical framework. Why, for instance, he heard the key of F from three A's that followed a G, only he will know; but that he did was something he sought to preserve.

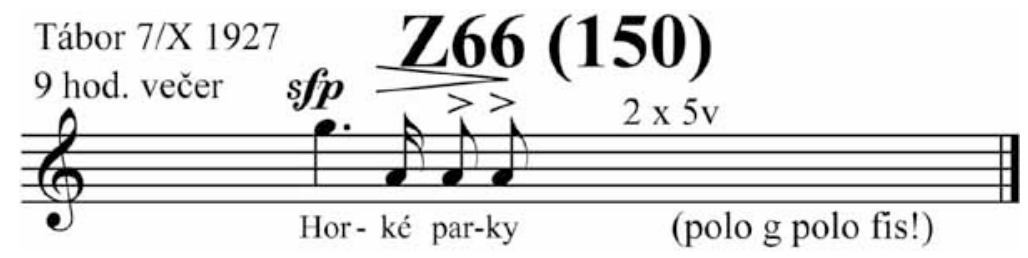

Fig. 21. Hot dogs! (Use the following link to download the audio file for this example: https://kb.osu.edu/dspace/bitstream/1811/24010/20/EMR000009a-Eaves21.ogg)

\section{Child Talk}

The speech of children, child-directed speech, and other language spoken in the presence of children, often acquire special qualities, absent from other speech registers. This sort of language typically contains wider pitch intervals or otherwise sounds more exaggerated than everyday speech. But these characteristics have for the most part gone unspecified as to the means by which they are achieved. We will take a look at a variety of nápěvky of this sort. You will recall Janáček's neighbor girl Lidka from Hukvaldy, whom we started with and whose delighted laugh we observed above (Figure 9). There are many more examples of her speech, some of which we will look at now. In 1901, Lidka was just an infant, but Janáček's ear was not without attention to the melodies of her voice. On the same page and just below her mellifluous laugh just referenced, Z22 (45), Janáček observes Lidka chce papat' [Lidka wants to eat] (Figure 21), which is illustrated by a motive of an eight-part repetition on the vocable me-. [51] Each of the eight quarter notes are given an accent mark, though no dynamic is struck for the whole. The melody,

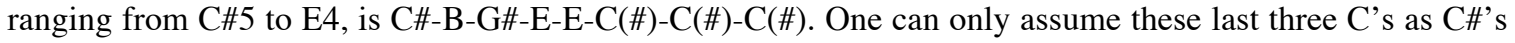
since the composer leaves off the accidental.

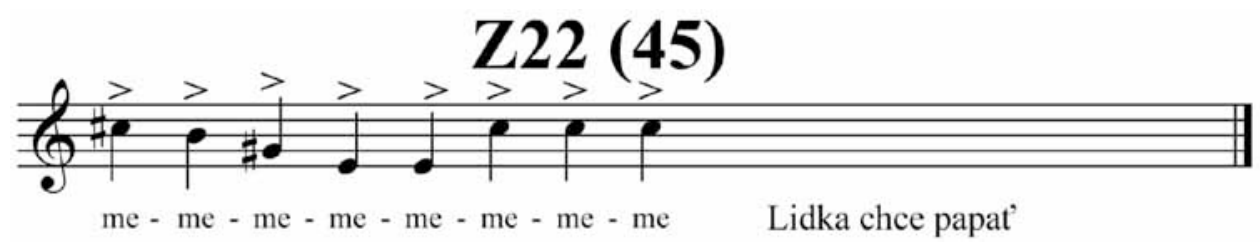

Fig. 22. Lidka wants to eat. (Use the following link to download the audio file for this example: https://kb.osu.edu/dspace/bitstream/1811/24010/21/EMR000009a-Eaves22.ogg)

No tempo is indicated, though one can surmise from the accents throughout that each note was clearly articulated and separate from those surrounding. Assuming such perceptual separation, one is likely to hear a break after the second E, with the leap back up to C\# creating a sense of pitch reset. Because of the outlining of a descending major triad (B-G\#-E), a sense of E-major tonality pervades, thus the final three pitches while level, thus directionally meaningless in isolation, are heard as a continuing contour, which corresponds neatly to Janáček's assessment that her babbling had the intent to command or request. Musically of course, these would be heard as the sixth scale degree, with the likely expectation that the melody would continue eventually with a drop to B, and a subsequent fall to the tonic.

A few years later, Lidka was talking more fluidly. In 1904, Z30 (33), we have a linguistic theme 
and variation (Figure 22). At first Lidka calls out, marked mf, Zavolaj mamo! [Call, mommy!]. [52] The rhythm proceeds: two sixteenths, followed by eighth-quarter-eighth, on a melody at the middle of the treble staff, B-B-A\#-B-A(\#). Two short one-word intonation units. The return to the B on the first syllable of mamo, cues a return to the baseline pitch, which along with the agogic accent on ma-serves to denote separation. Because of these factors, this interpretation is preferred to a hearing of one intonation unit with a primary accent on mamo. The contours (and pitches) of both halves are the same, a simple fall with an interval of a semitone. Musically, this is heard as two rhythmic variations on the same melodic fragment. Despite the descending semitone, which would normally strike the ear as incomplete, there is no strong indication of continuance (nor for that matter of finality). This holds both musically and prosodically. The sound context is simply too brief to create a strong sense of tonality, although a simple musical analysis would certainly give preference to B as tonic.
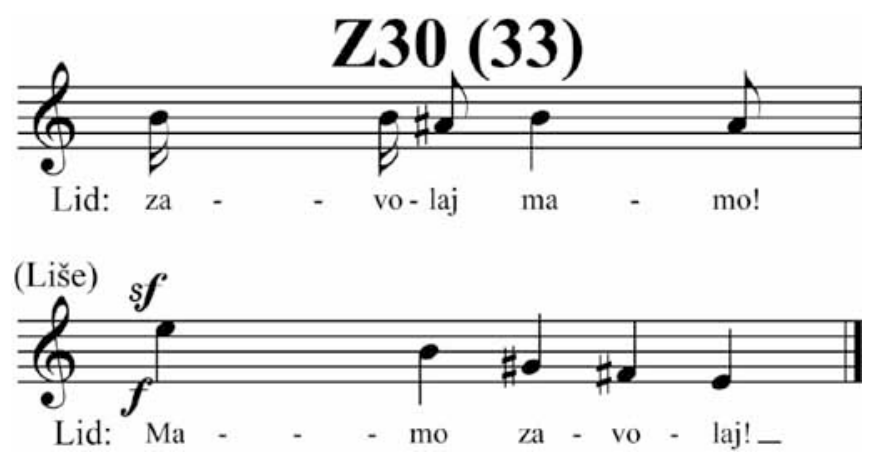

Fig. 23. Theme and variation. (Use the following link to download the audio file for this example: https://kb.osu.edu/dspace/bitstream/1811/24010/22/EMR000009a-Eaves23.ogg)

Following this and above the next example on the page, Janáček writes (Liše) [(she differentiates)]. The second example is marked $f$ at the bottom of the staff, with a $s f$ given at the top before the opening pitch. The order of elements is reversed here: Mamo zavolaj! [Mommy call!]. Each of the five syllables is set by a single quarter note, outlining a continuously descending line from E5 to E4: E-B-G\#F\#-E. Here the tonality is unequivocally that of E-major. The descending motive, lacking any repeated notes or changes in duration, connotes a single intonation unit, with a strongly final contour. The prosodic sense here corresponds exactly with the musical.

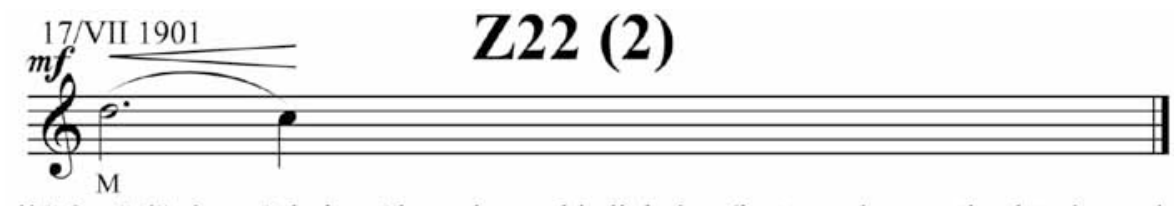

dítě 8 měsičné, napřahuje ručku - chce pohladit krávu (jest na rukou matky, která pase krávu).

Fig. 24. Stroke the cow. (Use the following link to download the audio file for this example: https://kb.osu.edu/dspace/bitstream/1811/24010/23/EMR000009a-Eaves24.ogg)

As we have seen, even in the absence of words, an infant's expressiveness, is not to be doubted. Above we have the example of Lidka wanting to eat (Figure 21). Here we have a desire of another sort. From 1901, Z22 (2), dated July 17, Janáček recorded a charming scene (Figure 23): dítě 8 měsičné, napřahuje ručku - chce pohladit krávu (jest na rukou matky, která pase krávu) [a child 8 months old, extends a little hand - she wants to stroke the cow (she is in the arm of [her] mother, who is pursuing the cow)]. [53] The child whines $m$-. The whine is presented by two notes, a dotted half followed by a quarter, written on a treble staff to the notes D5-C5, slurred together, with a crescendo marked above. A dynamic marking of $m f$ appears at the start. 


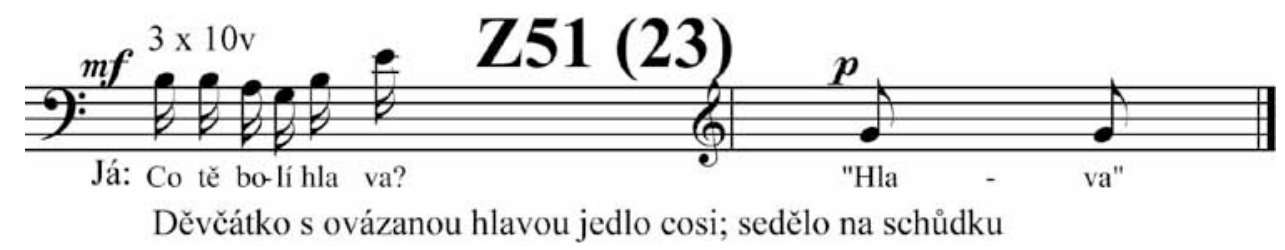

Fig. 25. Does your head hurt? (Use the following link to download the audio file for this example: https://kb.osu.edu/dspace/bitstream/1811/24010/24/EMR000009a-Eaves25.ogg)

Over the years, Janáček showed a fondness for the speech of children. On occasion he recorded his own speech melodies, interacting with the children. In a notebook from the year 1919, Z51 (23), we have a scene (Figure 24), dated 24 July, between Janá_ek and Děvčatko s ovázanou hlavou [A young girl with a bandaged head]. He continued the description jedlo cosi; sedělo na schůdku [she was eating something; she sat on a stoop.] It opens, bass clef, marked $m f$, Co tě bolí hlava? [What hurts (your) head?]. [54] Six even sixteenth notes are defined, set to the pitches B4-B4-A4-G3-B4-E4. To my ear, this is a typical Czech contour for this type of question. Possibly two intonation units, cued only by a return to the baseline, a middling pitch, in this case B4: The first part a descending melody; the prompt hlava? in the second part is an ascent, with a major pitch accent, in this case a rise of a P4. [55] The range is a M6, sitting in the middle low end of the available speaking register. The girl replies, marked $p$, somewhat slower, in even eighth notes, Hlava [(my) head], both syllables set to the same pitch, G4 in treble clef.

On Kounicova street in Brno, the $22^{\text {nd }}$ of October 1927, around 4:15 in the afternoon, Z66 (119), Janáček observed the following (Figure 25): the speaker is identified merely as Pani [a woman]; the motivation for what she says: malá, asi 3 let, děvčatko se "táhne" zemí [a small, about 3 year old, little girl is lingering behind her]. No pod'! [Well come on!] she calls, Honem! [Hurry!]. The entire utterance is marked $f$. A crescendo serves the first two words. The rhythm is a staccato sixteenth, a sixteenth rest, a tenuto double dotted quarter note, another sixteenth rest, followed by two more sixteenth notes. The melody begins high on $\mathrm{E} b 5$, drops a $\mathrm{m} 6$ to $\mathrm{G} b$, rises again to $\mathrm{C} b 5$, and falls again to $\mathrm{A} b 5$. The stark contrast in lengths between the staccato sixteenth of no [well] and the tenuto double dotted quarter of pod'! [come on!], as well as the wide interval traversed, serve to add extra emphasis to the imperative verb. The sixteenth rest furthers this aim, in highlighting the detached nature of the staccato no. The two sixteenths that follow give added impetus to the statement, wishing to impart the rushing quality of the prosody to the girl's movement.

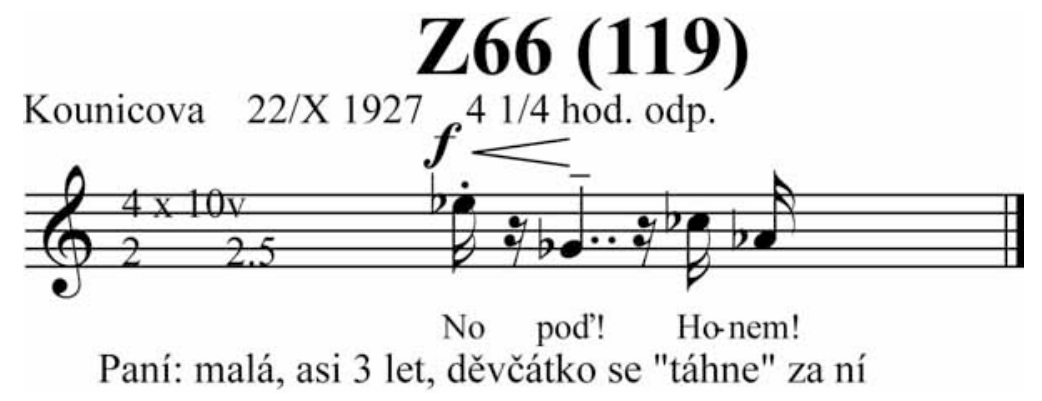

Fig. 26. Well come on! (Use the following link to download the audio file for this example: https://kb.osu.edu/dspace/bitstream/1811/24010/25/EMR000009a-Eaves26.ogg)

\section{One Final Salvo}

The last example, Z62 (96), is a reminder of the limits inherent in any attempt to capture and describe in simplified form the experiences of human life (Figure 26). Recorded on August 3, 1926, around 10:00 in the morning on Česká street, Janáček's notation presents us with the image of one boy hollering to a second the phrase Tažební listiny státních stavebních losu. [56] I sat for a long time trying to come up 
with a reasonable translation or approximation of just what this might mean. The words themselves are not a problem, literally they mean [A table of drawings for/from the state construction lotteries]. [57] But what do we make of that?

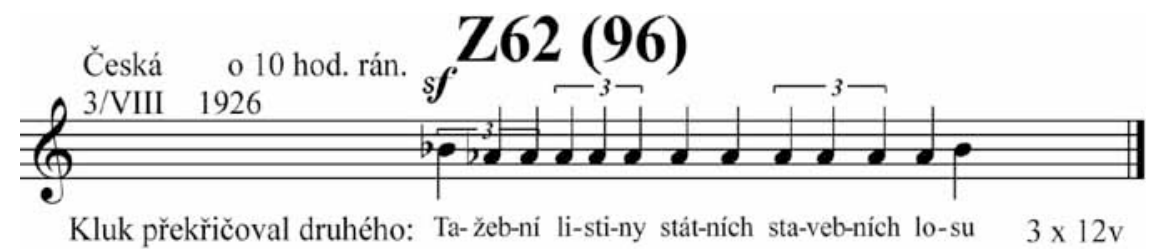

Fig. 27. A twofold mystery. (Use the following link to download the audio file for this example: https://kb.osu.edu/dspace/bitstream/1811/24010/26/EMR000009a-Eaves27.ogg)

Here is our friend the composer, at this point two months to the day past his $72^{\text {nd }}$ birthday, standing on the downtown street where he has so often found himself since his first arrival in Brno as a choirboy, more than 50 years before. He hears a public shout, and is drawn to the three-syllable words that trip upon each other as they dominate this utterance: He turns the notebook sideways, spine up, and notes the location, the date and time; he draws the familiar five-line staff by hand, marks a treble clef; $s f$ he scrawls at the top; Tažební, three triplet-quarters, $\mathrm{B} b-\mathrm{A} b-\mathrm{A} b$; he writes a decrescendo above; listiny, three more triplet-quarters, all on $\mathrm{A} b$; státních, two more quarters (not triplets this time), both on $\mathrm{A} b$; he places a tenuto above the first; stavebnich, three triplet-quarters on $\mathrm{A} b$, tenuto above the first; losu, two final quarter notes here, $\mathrm{A} b-\mathrm{B} b$, another tenuto over the first; he writes the words, and a brief description of the scene; then finally his cryptic marking for time $3 \times 12 v$.

What does he do then? Does he fold up the notebook and tuck it away? Does he hold it out in front of him, regard the boys, now halfway gone from his view, return his eyes to the page, and smile to himself, "yes, I captured them," like the self-satisfaction of a voodoo doctor, whose potion ensnares the spirit of his victims; only this potion is not an herbal one, but an auditory snapshot, scribbled in pencil on the mottled pages of his notebook number 62 ? And what was it that he captured, or was he himself enthralled by the sound? Did it in fact catch him, standing innocently on the street about to run his shopping errands, the sounds engrossing his mind, so that by necessity he writes them down, to release them from his thoughts, and thus release himself from them?

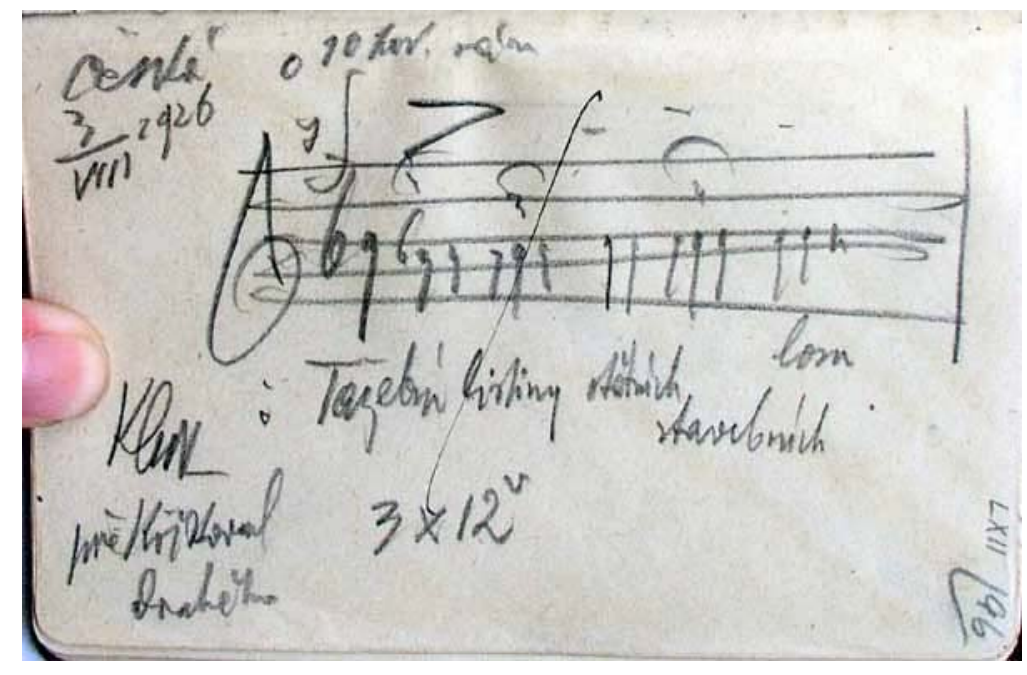

Fig. 28. Z62 (96) in Janáček's hand.

Tažební listiny státních stavebních losü [A table of drawings for the state construction lotteries] the boy had shouted to his companion. Was the second boy expected to remember to get the drawings, or to prepare them? Perhaps the words were a secret code that only the two of them understood. Triplet quarters- 
triplet quarters-quarter-quarter-triplet quarters-quarter-quarter, they pound on Janáček; he opens the book, his fingers firm, the pencil lead darkly set on the page; "write "em down, write 'em down ... ah there, now... that's better."

Today we wonder what the boy's shout implied. Perhaps Janáček himself wondered. But this was real. The shout rang clear; the transcription survives, hardly smudged, only the haste of his notating preserved gently in the cursive of his hand. Perhaps someday the meaning beneath the surface of these words, their melody and rhythm, will be deciphered more clearly than I have been able. Yet the time has passed. We are not, as Janáček was, privy to all the sights and sounds, the smell of downtown, the breeze in the air, softening the August heat and humidity of Brno. What remains is but a glimmer of these things, secondarily recreated on paper. The twofold mysteries of meaning and motivation remain: the boy's and the composer's.

\section{CONCLUSION}

Leoš Janáček has been described as a composer fascinated by the melodies and rhythms of speech. His notebooks for more than thirty years attest to this interest, and to the amount of energy he poured into the enterprise. Janáček was not drawn however to the beautiful melodies of nature for inspiration, at least not in the usual sense. Contrarily, with an eye towards a new kind of realism, he sought to immerse himself in naturalistic observations of the ordinary, and thus endrench his music with what he gleaned from them. Just how that process may have taken place (or even the degree of his success in transforming the one into the other) remains subject to debate.

He was never quite explicit in his writings; subsequent attempts to find evidence of speech melodies as motives in his music have been strained. In part, I believe this is because previous efforts have been misguided, too attached to the appearance of notes on a page to look deeper than the surface. They have perhaps unwittingly been guided by an attempt to find evidence in support of Nejedlý's contention that Janáček's composing was not so much a creative enterprise as one of merely piecing together collected speech melodies, in a collage as it were. But such a procedure hardly makes sense, even if Janáček himself had not vociferously denied the possibility of such an act (Janáček, 1928). Indeed, if the composer were merely seeking musical inspiration, why turn to speech?

Many if not most of the recorded nápěvky are musically unremarkable. They are brief, sometimes a mere one or two notes in length. Since it is all but inconceivable that anyone would have stitched these fragments together-and in any case we have no evidence that Janáček followed this sort of collage procedure -it behooves us as latter day theorists to change our tack, and seek to understand these nápěvky on their own terms. If what appears on the surface is unremarkable, it rests with us to comprehend what would motivate the composer to expend so many hours of his time, during more than three decades, in gathering these snippets of sound. Conversations in situ, like brief extracted musical phrases, reside within a larger framework.

We must remember, that what is important, in both music and speech, is not always mathematical precision, but the effect of perception on that which is being perceived. Janáček's motivation in capturing these nápěvky must always be seen in the light of his attempt to recreate the experience of passionate human beings within the animate world in which they dwelt. Despite the veil of science that he sought, to cloak his efforts in objectivity -in using a Hipp's chronoscope for instance, or his assiduous study of Wundt's Völkerpsychologie - he never lost sight of this goal. What the present study adds to the discussion is a greater appreciation for Janáček's investigations of speech prosody, and the meanings that underlie this stratum of expressiveness. Previous efforts have focused on the musical notes alone with little commentary on the linguistic elements that gave rise to the surface permutations he perceived and which he set down to paper in the guise of music. Janáček was not only a composer, pedagogue, and essayist, but also a pioneer in the study of speech prosody, and in a way of music cognition. There is great potential in following up on his work, likely leading to closer collaborations between musicologists and linguists. Through crossfertilization of ideas, we will reap a richer harvest.

\section{NOTES}

[1] The present paper is derived and updated from the author's Ph.D. dissertation (Pearl, J., 2005), which was supported in part by a Fulbright grant to the Czech Republic, 2003-2004. 
[2] While surely it is natural to wonder just how these speech melodies may have appeared in Janáček's music, it is somewhat more complicated, or perhaps more simple, a matter. The existing musicological literature on Janáček's speech melodies has so far been rather inconclusive in attempts to find direct applications in his compositions. See, Christiansen (2002, 2004); Katz (2000); Tyrrell (1970); Wolff (1970). The simplest explanation is that they have been looking in the wrong way. Janáček's essays, while declaring the importance of studying real motives, including those found in speech, do not articulate a method for transfering these objets trouvés into musical compositions. Perhaps the most fruitful interpretation, though one sure to frustrate many, is that Janáček sought in his studies more inspiration than material, that he immersed himself in the motives of nature in order to absorb them into his artistic thought, just as W.A. Mozart, when seeking to write Italianate operas, internalized their form and sound, rather than borrowing from their substance.

[3] Translations are those of the author, unless otherwise noted.

[4] I especially thank Prof. Jan Chovanec, of Masaryk University, for discussion of these matters. His commentary served to amplify my view that Janáček's language permits of multiple interpretations.

[5] Translated here as "grows up with me in notes." The similar and more common expression studovat u někoho [to study under someone] indicates a master-apprentice relationship. However, I've not seen any evidence to support this view, for instance, that Janáček provided music lessons for his neighbors' children.

[6] Straková \& Drlíková, Eds. (2003) alone includes more than two dozen such articles.

[7] His notebook from 1897-1900 (dubbed Z20 in the archives of the Moravian Museum in Brno) contains the first known examples of his náp̌evky mluvy.

[8] This association with subsequent generations is something reflective of Janáček's thinking and behavior, as well as typical to his treatment in the literature. Musically, he is more often associated with those one or two generations younger than he (Bartók, Martinů, Křenek, Stravinsky), rather than with his own contemporaries. Cf. Katz, D. (2000), pp. 4-17.

[9] For a brief history of the field see Cruttenden, A. (1996), pp. 26-28.

[10] His library contained only three items in English: First, the article "The Musical Nature of Speech and Song," by Richard A. S. Paget (1924), Proceedings of the Musical Association, v. 50. The utter lack of any marks or notations here by Janáček lead me to suspect he never read it. The second item, interestingly in light of Beckerman's (2003, pp. 84-87) recent revelations regarding Dvořák, was the music anthology The Second Book of Negro Spirituals, edited with an introduction by James Weldon Johnson, and musical arrangements by J. Rosamund Johnson (New York: The Viking Press, 1926). The final item was a collection of folk songs, (Sharp, Cecil J., 1908, Folk-songs from Somerset, London: Novello \& company).

[11] Nor do we yet have data from contemporary spoken Czech. There is an ongoing project called the Czech National Corpus, which contains a modicum of audio recordings. But these have yet to be analyzed from a prosodic standpoint. In getting such a project underway, we have a unique opportunity to forge ties between the musicological and linguistic communities in the Czech Republic, that might hopefully be duplicated elsewhere.

[12] Gardiner (1980) presents a recent case in favor of musical transcription of language, in particular of the Czech language. Oddly, in the entire book, there is not a single mention of Janáček, a glaring absence.

[13] Monrad-Krohn (1963) recognizes four categories of speech prosody, which he termed: intrinsic prosody (corresponding roughly to lexical prosody), propositional prosody, emotional prosody, and prosodic grunts.

[14] Synchronic comparisons have appeared in the literature, but sparely and incompletely, and mostly 
dealing with citation form production, rather than spontaneous speech. See, Collier (1991); Delattre (1963); Fox (2000); Jun (2005). An exception to this in terms of synchronic comparison can be found in Ross, Edmondson, and Seibert (1986), which compares the acoustic features of affective prosody in English with those of three tone-languages (Taiwanese, Mandarin, \& Thai). This appears however to be the only such study extant. It is important to note in this regard that despite "tone" being encoded at the lexical level in so-called tonal languages, emotional prosody can nonetheless be produced through various acoustic manipulations. It is simply that the specific features manipulated vary by language. In terms of comparisons to musical experience, see Patel \& Danielle (2003) and Patel, et al. (2006). Thanks to Aniruddh Patel for comments and specific citations in this regard.

[15] In keeping with the cataloging system of the Moravian Museum, I shall label the notebooks Z\#\#, which appear in roughly chronological order. Page numbers within each notebook will be enclosed in parentheses following the notebook number.

[16] Nápěvky mluvy was a coinage by Janáček himself. Nápěv is the Czech word meaning tune or melody. Nápěvek is the singular form of nápěvky, and is merely a diminutive form of the root word. Because this diminutive is so associated with Janáček and his work on speech melodies, I use it as a general synonym for "speech melody" as represented in Janáček's transcriptions. One further note: the term nápěv shares a morphemic root with the word zpěv meaning "the act of singing." It's no wonder that Janáček found the term appropriate to his purposes.

[17] One unresolved issue is the accuracy of his memory and recall, even in the cases where the transcription occurred immediately following the event, which was not always the case. Unfortunately, there has been negligible research dealing with memory for prosodic features in speech. Even where memory for words and melody have been studied, they have exclusively utilized "musical" examples (songs rather than speech), or have dealt with the memory for spoken words without regard to recall of the associated intonation. Cf. Crowder (1993); Serafine, Crowder, and Repp (1984); Serafine, Davidson, Crowder, and Repp (1986); Crowder, Serafine, and Repp (1990); Samson and Zatorre (1991); Wallace (1994).

[18] van Waesberghe (1957) in a somewhat disappointingly superficial approach to the subject echoes Henry Sweet (1877) in arguing that one distinction between speech and song is that music is characterized by a finite number of discrete pitches, whereas speech intonation is characterized by an infinite quantity of possible tones. He oddly proposes that listeners are unable to hear subtle variations in pitch when the stimuli are musical, but are quite adept at noticing these modifications in speech. He rightly indicates that the perception or non-perception of such nuances is largely a matter of the listener's attitude, though he fails to suggest that these attitudes (or attentions) are likely determined by the individual's enculturation, as much as by their desires.

[19] The Czech composer and pedagogue, Alois Hába (1893-1973), noted for his work with intervals smaller than those of the chromatic scale, in particular quarter-tones, was not active until nearly the end of Janáček's life, his first quarter-tone work dating from 1920. (Cf. The Concise Baker's Biographical Dictionary of Musicians, 8th edition, s.v. "Hába, Alois."). Janáček was without a doubt aware of these developments in music, though they seem not to have had any impact on his transcription practice.

[20] Translation from Zemanová (1989), pp. 101-102.

[21] The linguist Jane Edwards (1993, p. 3) has remarked that "no transcript is completely theory neutral or without bias."

[22] The insistence by some composers that performances follow their notation as precisely as possible, as for instance Igor Stravinsky, is perhaps an elegant argument that this flexibility is commonplace and openly acknowledged. Indeed, today some composers prefer computer-generated sound to human performers as a means to diminish the variance that occurs through live performance.

[23] In order to provide the readers with a better sense of these examples, and to take full advantage of the 
potentials of the online nature of this journal, sound files will accompany each of the illustrated transcriptions. The question inevitably arises as to whether Janáček provided tempi for his nápěvky. Alas, for the most part, he neglected to specify this aspect of performance. The marking lehce [lightly] in Pak pojd' když tě volám below is the closest he comes in any of the examples here. However, you will note in some examples the markings "4 x $11 \mathrm{v}$ ", " 2 x 5 v", " 3 x $10 \mathrm{v} "$ ", etc. The Czech abbreviation for a second vteřina is "v". Yet, these clearly do not indicate duration in seconds which would be inconceivably long for these examples. Rather, they have to do with his Hipp's Chronoscope readings. Yet greater clarification of his markings is elusive. I can't say whether he carried the device around with him, and measured speech on the spot (which seems unlikely), or whether he rendered readings after the fact from his own recreation from the transcriptions. Nor indeed, can I decipher the meaning of his numbers. I consulted colleagues who have also worked with Janáček's speech melodies, to no avail. Further, I consulted an expert in the history of psychological instrumentation, Tom Perera, Emeritus Professor at Montclair State University. He explained (personal communication) that the "Hipp Chronoscope was frequently hooked up to a voice key; a diaphragm-operated switch that detected vocalizations," the times between successive vocalizations being recorded in 1000ths of a second.

[24] The question of meaningfulness or the semantics of musical materials is a fascinating one, but one which most will agree lends itself to greater polysemy than standard linguistic materials do. Yet it is this very polysemy in approaching speech prosody that has so befuddled researchers in this domain. I hope what emerges through the course of this investigation is just how similar these questions become if we only take the time to consider them.

[25] It is an open but empirically testable question whether or not anacrusis in music is normally characterized by this same quickening of tempo.

[26] This is akin to a return to tonic or to a recitation tone in chant, though normally linguistics speaks of pitch reset as beginning a segment, whereas music theoretically expects a return to the baseline pitch at the end of a phrase or section. Cf. Gardiner (1980, pp. 6-7, 36, 39, 86, 93, and elsewhere).

[27] Cf. Chafe's discussion of intonation units (Chafe, 1994, pp. 57-70). While Chafe describes different sorts of intonation units, including what he calls regulatory units, conjunctions are not in this context explicitly dealt with separately. Chafe does mention conjunctions (p. 80) in the context of function words, which carry what he terms "non-idea information." However, it would seem that, in addition to their role specifying the relationships among actors and ideas, conjunctions often serve the same function as pauses or "filled pauses," namely permitting the speaker some cognitive space for formulating what is to come next. Thus, the placement of conjunctions at the beginning of intonation units would follow the transcriptional convention for pauses. However, as noted, conjunctions seem to serve a transitional function both prosodically and syntactically, which is supported by the evidence of anacrusis and delayed pitch reset as described.

[28] Some work along these lines has already been begun by Rytis Ambrazevičius (2005). In particular, he has examined the scales produced by traditional folk singers, and compared these acoustically verifiable scales with the self-reported perceptions and intentions of the singer. As one might suspect, the singer's approach to pitch in actual performance comes much closer to what is seen in spontaneous speech, than what one might expect from a trained concert performer.

[29] Chafe (1994, pp. 186-191) commits an entire book chapter to just these sorts of considerations.

[30] Paul Christiansen (2002, pp. 107-109) discusses this same nápěvek (as example 4.2). He identifies the speaker as "Mrs. Rakovičová," and translates the utterance as "Yes, nice it certainly would be". Further, he notes, that the final accent mark in pěkne is absent. He specifies the intended word as the adjective pěkné, though the adverb pěkně is also possible.

[31] As noted before, there is some evidence of their having first met as early as 1881, however 1886 is clearly established as a date when they both taught at the same school. Their known correspondence begins in 1890, by which time their close friendship is apparent (Straková, 1957). 
[32] Takovy would present a word about as odd to listeners as "ratherly" sounds in English, rarely if ever used. In contrast, the word takový/takováltakové (meaning literally "of a sort" or "some kind of" is quite common, and often used as filler while thinking of the next word, or to add emphasis to whatever is to follow. The adverb corresponding to divný is divně, the $\check{e}$ being an alternate ending for the formation of adverbs.

[33] These were among the issues discussed in the presentation "Hypothetical Universe: a functionalist critique of Lerdahl-Jackendoff" given by this author at the conference of the Society for Music Perception and Cognition, June 2003, in Las Vegas. Some of the relevant section follows: "Although this is a rather small sample, some patterns emerge. For example, note that cues 20 and 41 are the longest quarter notes in their clusters, and that this corresponds to their penultimate positions. In further analysis, we might suspect that this pattern might be sustained for this performer, and possibly for other performers. If so, we could theorize that lengthening in penultimate position of groups is accommodated or expected by our hearing. That is, even though timing varies by as much as $20 \%$, this does not lead us to hear these note values as different." The referenced paper and related data and sound files can be accessed at the following URL: http://www.musiclanguage.net/conferences/presentations/hypothetical-universe/

[34] This same articulation mark appears in the example above, in addition to an accent mark, accompanying the syllable po-.

[35] One unusual feature of the Czech language is the use of the laterals $l$ and $r$ as quasi-vowels, thus permitting syllables and whole words which contain no vowels proper (for instance: prst [finger], trh [market], trn [thorn], $k r k$ [throat/neck]).

[36] Sharing the same number of syllables, the English gloss could even be intoned in the same fashion. The following nápěvek, immediately beside this one on the page, reads jak sme vystoupili z lodí [how we debarked from the ships], with Janáček's parenthetical remark below both vykládal živě o své cestě do Stokholmu [He expounded animatedly about his trip to Stockholm]. Thus the context is apparent.

[37] Thanks to Bob Ladd and Anirrudh Patel for discussion of this question.

[38] The Czech construction mít rád (in this case conjugated in the present tense and gender-marked feminine as mám ráda) literally means "to have gladly." It is functionally and semantically equivalent to the German expression haben gern.

[39] Dneškaj is a vernacular variant for dneska [today], which itself is an adverbial form of dnes [today]. Dobře is actually an adverb, literally "well". The adverb is more often used than in English for expressions regarding personal state or mood, as in Jak se máš? Dobře. [How are you? Well.].

[40] An alternate interpretation, however, is that the man is engaged in splitting stone, perhaps working in a quarry. The context of the utterance is left to our imaginings, since it was not recorded. This is an unfortunate difficulty in doing this sort of work with historical documents, and argues forcefully for better preserving relevant contextual and ethnographic data in contemporary projects. The analysis stands, though the speaker's motivation for hesitating remains hidden.

[41] This is almost certainly the linguist and ethnographer František Bartoš, Janáček’s longtime friend and collaborator.

[42] The apostrophe following the $t$ is Czech orthography for palatalization.

[43] I've never heard it uttered in my decade of visits to the Czech Republic.

[44] Czech prepositions are often comprised of a single consonant $(s, k, v, z)$ which in pronunciation latches to the following syllable, presenting a voiced or unvoiced allophone corresponding to the character of the subsequent sound. 
[45] Standard spelling would result in: Tak já už jdu!

[46] Czech is considered a pro-drop language, meaning the pronominal subject (in this case já [I]) is optional.

[47] "Then" meaning "in that case" rather than a time. Pak and the related $t a k$ [so] are ubiquitous in spoken Czech.

[48] The spelling Pod' is apparently a phonetic picture of the boy's pronunciation of the imperative pojd'. Interestingly, this example appears in all ways the same as here and in his notebooks, except the word order was changed (pod' sem pod' sem já ti něco povím) in the article "Nápěvky naší mluvy vynikající zvláštní dramatičnostî" (Janáček 1903a; see Straková \& Drlíková 2003, p. 297). Thanks to Dr. Eva Drlíková, who confirmed this from Janáček's correction proofs for that article.

[49] Properly, the first two words should contain long vowels (já and vám respectively), but Janáček seems to be intent to point out actual vowel length of the pronunciation, rather than the customs of writing. Thus the only long vowel he marks is that corresponding to the only half note of his transcription. He is not entirely consistent in this regard, however, sometimes writing an length mark on a syllable where no corresponding length appears in his notation.

[50] Toilet in the French sense of washing up. Thanks to Jana Chamonikolasová for clarification in this matter.

[51] The verb papat, or as spelled here papat', is reserved for children, with a bit of onomatopoeia to it; thus it might in some circumstances be translated as something like "yum-yum". Janáček's verb spellings often reflect either final palatalization, as here, or $-t i$ at the end. These quirks are the remnants of a nowarchaic spelling, perhaps evidencing the dialectic he was accustomed to.

[52] Mámo is the vocative form (here given without the long á), thus the imperative call is directed to her mother.

[53] I have taken some license in translating the child as a girl. The gender of the child however is unrevealed in the original. The word dítě, like its English gloss "child," is neuter in gender. Czech verbs mark gender only in the past tense, thus no cue is provided.

[54] Identified below the staff, just before the text of the utterance, Janáček wrote $J a ́$ [I]. The Czech expression is literally "what hurts you the head?".

[55] It would be possible of course to consider this a single intonation unit, rather than two, with the primary accent contained by hlava [head] and a secondary accent on bolí. In this case, I believe the matter is subjective. There is only one cue to separation, the pitch reset, since all durations are presented as the same length. In actual performance, there may or may not be a slight lengthening on boli [hurts] and or rushing on the syllable hla-, which might further support my preferred interpretation here. An interesting comparison would be between the rhythm of a spoken performance, and the actual rhythm of a musical performance of this same motive. Would these slight alterations in timing correlate between the two? If so, we have another striking parallel between these two domains of human behavior (music and language), drawing them closer together. If not, we have cause to theorize as to what differs between the rhythmic processing for each domain.

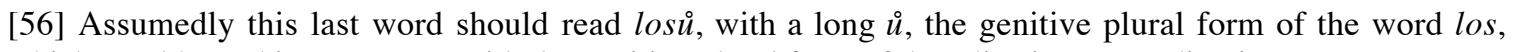
which would stand in agreement with the genitive plural form of the adjectives preceding it.

[57] The final three words are in genitive case. 


\section{REFERENCES}

Ambrazevičius, R. (2005). Psichoakustiniai Bei Kognityviniai Muzikinès Darnos Aspektai ir Ju Raiška Lietuviu Tradiciniame Dainavime [Psychoacoustic and Cognitive Aspects of Musical Scales and their Manifestation in Lithuanian Traditional Singing]. Doctoral dissertation, Lithuanian Academy of Music and Theatre, Vilnius.

Beckerman, M. (2003). New Worlds of Dvořák, New York: W.W. Norton \& Co.

Belin, P., Zatorre, R., Lafaille, P., Ahad, P., \& Pike, B. (2000). Voice-selective areas in human auditory cortex. Nature Vol. 43, pp. 309-312.

Broch, O. (1911). Slavische Phonetik: Sammlung slavischer Lehr- und Handbücher. Heidelberg: A. Leskien u. E. Berneker.

Chafe, W. (1988). Punctuation and the prosody of written language. Written Communication Vol. 5, No. 4, pp. 396-426.

Chafe, W. (1994). Discourse, Consciousness, and Time: The flow and displacement of conscious experience in speaking and writing. Chicago \& London: The University of Chicago Press.

Chlumský, J. (1911). Pokus o měření českých zvuků a slabik v řečí sovislé. Prague: České akademie.

Christiansen, P. (2002). “Sounds of the Soul”: Leoš Janáček's Conception of Speech Melody. Ph.D. dissertation, University of California, Davis.

Christiansen, P. (2004). The meaning of speech melody for Leoš Janáček. Journal of Musicological Research, Vol. 23, pp. 241-263.

Collier, R. (1991). Multi-language intonation synthesis. Journal of Phonetics 19: pp. 61-73.

Crowder, R. (1993). Auditory memory. In: S. McAdams \& E. Bigand (Eds.), Thinking in Sound: The Cognitive Psychology of Human Audition. Oxford: Clarendon Press.

Crowder, R., Serafine, M, and Repp, B. (1990). Physical interaction and association by contiguity in memory for the words and melodies of songs. Memory \& Cognition, Vol. 18, No. 5, pp. 469-76.

Cruttenden, A. (1996). Intonation, $2^{\text {nd }}$ Ed. Cambridge, UK: Cambridge University Press.

Delattre, P. (1963). Comparing the prosodic features of English, German, Spanish, and French. International Review of Applied Linguistics 1, pp. 193-210.

Du Bois, J., Cumming, S., Schuetze-Coburn, S. \& Paolino, D., Eds. (1992). Santa Barbara Papers in Linguistics, v. 4: Discourse Transcription. Santa Barbara: University of California, Santa Barbara, Department of Linguistics.

Du Bois, J., Schuetze-Coburn, S., Cumming, S., \& Paolino, D. (1993). Outline of discourse transcription. In J. Edwards \& M. Lampert (Eds.), Talking Data: Transcription and Coding in Discourse Research. Hillsdale, NJ: Lawrence Erlbaum Associates, pp. 45-89.

Deutsch, D., et al. (2004). Absolute pitch, speech, and tone language: Some experiments and a proposed framework. Music Perception Vol. 21, pp. 339-356.

Edwards, J. (1993). Principles and contrasting systems of discourse transcription. In: J. Edwards \& M. Lampert (Eds.), Talking Data: Transcription and Coding in Discourse Research. Hillsdale, NJ: Lawrence 
Erlbaum Associates, pp. 3-31.

Fox, A. (2000). Prosodic Features and Prosodic Structure: The Phonology of Suprasegmentals. Oxford: Oxford University Press.

Gardiner, D. (1980). Intonation and Music: The Semantics of Czech Prosody. Bloomington, IN: Physsardt Publications.

Hála, B. (1957). The Slavonic Languages. In L. Kaiser (Ed.) Manual of Phonetics. Amsterdam: North Holland Publishing, pp. 302-311.

't Hart, J, Collier, R, and Cohen, A. (1990). A Perceptual Study of Intonation: An Experimental-Phonetic Approach to Speech Melody. Cambridge: Cambridge University Press.

Hostinský, O. (1886). O české deklamací hudební. Prague: [Publisher unknown].

Janáček, L. (1903a). Nápěvky naší mluvy vynikající zvláštní dramatičností, Časopis Moravského muzea Vol. 3, pp. 105-112; Hlídka Vol. 20., pp. 636-637. Reprinted in T. Straková, \& E. Drlíková, Eds. (2003), pp. 296-301.

Janáček, L. (1903b). Moje Luhačovice, Hlídka Vol. 20, pp. 836-844; Reprinted in T. Straková, \& E. Drlíková, Eds. (2003), pp. 301-309.

Janáček, L. (1904). Nápěvky dětské mluvy, Český lid, Vol. 13-15. Reprinted in T. Straková, \& E. Drlíková, (Eds.), Leoš Janáček: Literární dílo, I. Brno: Editio Janáček, pp. 313-328.

Janáček. L. (1924). Scestí. Listy Hudební matice, Vol. 4, Nos. 1-2, pp. 1-4. Reprinted in Straková \& Drlíková, Eds. (2003), pp. 546-49.

Janáček, L. (1928). Dva interviewy, Literární svět, Vol. 1, No. 12. Reprinted in Straková \& Drlíková, Eds. (2003), pp. 616-18.

Jun, S.-A., Ed. (2005). Prosodic Typology: The Phonology of Intonation and Phrasing. Oxford: Oxford University Press.

Kassler, J. (2005). Representing speech through musical notation. Journal of Musicological Research, Vol. 24, Nos. 3-4, pp. 227-239.

Katz, D. (2000). “A pen filled only with my own passion”: Leoš Janáček and the Grand Operatic Traditions. Ph.D. dissertation. University of California, Santa Barbara.

Kimura, D. (1967). Functional asymmetry of the brain in dichotic listening. Cortex, Vol. 3, pp. 163-178.

Ladd, D. (1996). Intonational Phonology. Cambridge, UK: Cambridge University Press.

Monrad-Krohn, G. (1963). The Third Element of Speech: Prosody and Its Disorders. In L. Halpern (Ed.), Problems of Dynamic Neurology. Jerusalem: Hebrew University, pp. 101-18.

Levitin, D. (1994). Absolute memory for musical pitch. Perception \& Psychophysics, Vol. 56, No. 4, pp. 414-423.

Oxford English Dictionary online (http://dictionary.oed.com), $2^{\text {nd }}$ edition (1989).

Patel, A., \& Daniele, J. (2003). An empirical comparison of rhythm in language and music. Cognition 87: pp. B35-B45. 
Patel, A., Iversen, J., \& Rosenberg, J. (2006). Comparing the rhythm and melody of speech and music: The case of British English and French. Journal of the Acoustical Society of America, Vol. 119, pp. 3034-3047.

Pearl, J. (2005). The Music of Language: The Notebooks of Leoš Janáček. Ph.D. dissertation. University of California, Santa Barbara.

Pinker, S. (1997). How the Mind Works. New York: W.W. Norton \& Company.

Randel, D. (1986). New Harvard Dictionary of Music. Cambridge, MA \& London: Belknap Press of Harvard University Press.

Ross, E., Edmondson, J., \& Seibert, G. (1986). The effect on affect of various acoustic measures of prosody in tone and non-tone languages: A comparison based on computer analysis of voice. Journal of Phonetics, Vol. 14, pp. 283-302.

Samson, S., \& Zatorre, R. (1991). Recognition memory for text and melody of songs after unilateral temporal lobe lesion: Evidence for dual encoding. Journal of Experimental Psychology: Learning, Memory, and Cognition, Vol. 17, No. 4, pp. 793-804.

Serafine, M., Crowder, R., and Repp, B. (1984). Integration of melody and text in memory for songs. Cognition, Vol. 16, pp. 285-303

Serafine, M., Davidson, J., Crowder, R., and Repp, B. (1986). On the nature of melody-text integration in memory for songs. Journal of Memory and Language, Vol. 25, pp. 123-35.

Straková, T., Ed. (1957). František Bartoš a Leoš Janáček: vzájemná korespondence. [Brno]: Krajské Museum v Gottwaldově.

Straková, T. \& E. Drlíková, Eds. (2003), Leoš Janáček: Literární dílo, I. Brno: Editio Janáček.

Sušil, F. (1863). Krátka prosodie česká, 3rd revised edition. Brno: A. Nitsche.

Sweet, H. (1877). A Handbook of Phonetics. Oxford: Clarendon Press.

Trávníček, F. (1924). Př́spěvky k nauce o české př́izvuku. Brno: Spisy filosofické fakulty Masarykovy university.

Tucháček, E. (1920-1921). Poznámky o zjevech fonetických. Žívé Slovo, Vol. II, No. 1-4.

Tyrrell, J. (1970). Janáček and the speech-melody myth. Musical Times, Vol. III, No. 1530: pp. 793-796.

de Waal, F. (2001). The Ape and the Sushi Master. New York: Basic Books.

van Waesberge, J. (1957). Phonetics in its relation to musicology. In L. Kaiser (Ed.), Manual of Phonetics, Amsterdam: North Holland Publishing.

Wallace, W. (1994). Memory for music: Effect of melody on recall of text. Journal of Experimental Psychology: Learning, Memory, and Cognition, Vol. 20, No. 6, pp. 1471-1485.

Wolff, H. (1970). "Ralistische und expressive Sprachmelodie zur Zeit Janáčeks," in R. Pečman, Ed., Colloquium Leoš Janáček et Musica Europaea, Proceedings from the International Musical Festival, Brno 1968.

Zemanová, M., Ed. \& Trans. (1989). Janáček's Uncollected Essays on Music. New York: Rizzoli International. 